\title{
27. SILICOFLAGELLATES AND EBRIDIANS FROM THE NEW JERSEY TRANSECT, DEEP SEA DRILLING PROJECT LEG 93, SITES 604 AND 605
}

\author{
Kevin McCartney and Sherwood W. Wise, Jr., Florida State University ${ }^{2}$
}

\begin{abstract}
Well-preserved and diverse silicoflagellate and ebridian populations are found in the lower and middle Eocene sediments of DSDP Site 605 and the upper Miocene sediments of DSDP Site 604. The ebridians outnumber the silicoflagellates in the siliceous interval of Site 605, but are less numerous at Site 604. The abundances of the various taxa are tabulated.
\end{abstract}

\section{INTRODUCTION}

Deep Sea Drilling Project Leg 93 drilled Sites 604 and 605 on the upper continental rise some $161 \mathrm{~km}$ (100 mi.) southeast of Atlantic City, New Jersey (Fig. 1). These holes are an integral part of the "New Jersey Transect," a series of holes providing the first dipwise traverse of a passive continental margin from the coastal plain to the abyssal plain. Well-preserved silicoflagellates were recovered at both sites. The oldest assemblages, early middle Eocene in age, were present in a silica-rich nannofossil chalk, $152 \mathrm{~m}$ thick, at Site 605 . Site $604,5 \mathrm{~km}$ seaward of Site 605, yielded upper Miocene assemblages from a glauconitic, silica-rich silty claystone deposited along with conglomeratic debris flows. Silicoflagellates elsewhere in these sections were poorly preserved or largely reworked and are not treated further here.

Exploration of the North Atlantic basin over the last two decades, including a dozen DSDP legs, has provided many localities in which Cenozoic silicoflagellates were sufficiently numerous or well preserved to be described in some detail. These studies have been summarized by Bukry (1978c, 1981b) and are tabulated in Table 1. Of these, DSDP Legs 43,44 , and 78 were drilled within the North American Basin.

Along the Atlantic margin of North America, silicoflagellates were described (as radiolarians) from the Miocene of Maryland as early as 1904 (Martin, 1904) and later, in more detail, by Tynan (1957). Silicoflagellates have since been described in stratigraphic studies of the Miocene of Georgia, South and North Carolina (Ernissee et al., 1977; Abbott and Ernissee, 1983), and in Abbott's analyses (Abbott, 1978, 1980) of siliceous microfossil assemblages recovered in AMCOR, JOIDES, and Atlantic Slope Project (ASP) wells cored offshore from Florida to Massachusetts. Most of these latter sites yielded Miocene or younger assemblages, but one, ASP 22, recovered Oligocene silicoflagellates (Abbott, 1980).

\footnotetext{
${ }^{1}$ van Hinte, J. E., Wise, S. W., Jr., et al., Init. Repts. DSDP, 93: Washington (U.S. Govt, Printing Office).

2 Addresses (McCartney, Wise): Dept. of Geology, Florida State University, Tallahassee, FL 32306-3026.
}

\section{SAMPLE PREPARATION AND METHODS OF STUDY}

Raw samples were placed in $100 \mathrm{ml}$ beakers and a small amount of $30 \%$ hydrogen peroxide added; more was added if it strongly effervesced. After 2-4 hr. (or longer if effervescence continued when more hydrogen peroxide was added), the beaker was placed in an ultrasonic cleaner and distilled water was added to about the $25 \mathrm{ml}$ level. $\mathrm{HCl}$ was added and the beaker heated for $30 \mathrm{~min}$. Samples were then centrifuged and decanted twice and washed once before strewn slides were made. For similar methods of slide preparation, see Bukry (1983) and Busen and Wise (1977).

Although a general practice is to count 300 specimens per sample, the silicoflagellate abundance in this study area was not sufficient to allow such counts without a prohibitive investment of time. Laws (1983) has shown that the microfossils on a smear slide may become segregated by size, so all of the specimens on each slide (with a $22 \times 40 \mathrm{~mm}$ cover slip) were counted. Fragments representing more than half of the original skeleton were included in the counts.

\section{SITE SUMMARIES}

\section{Site 604 (Table 2)}

Hole $604\left(38^{\circ} 42.79^{\prime} \mathrm{N} ; 72^{\circ} 32.95^{\prime} \mathrm{W}\right.$; water depth, $2364 \mathrm{~m}$ ) was drilled on the uppermost continental rise, 100 n.mi. $(161 \mathrm{~km})$ southeast of Atlantic City, as the seaward end-member of the New Jersey transect. The section consists of $239 \mathrm{~m}$ of Quaternary to upper Miocene dark clays and silts with variable amounts of biogenic silica and glauconitic shelf sand turbidites (lithostratigraphic Units I and II; see Site 604-605 chapter, this volume) that overlie $56 \mathrm{~m}$ of upper Miocene glauconitic, biosiliceous, silty claystone, sand, and conglomerate (lithologic Unit III). The last two components were emplaced largely as turbidites or debris flows. Workable numbers of silicoflagellates were present in 13 samples of biosiliceous claystone spanning an interval from the bottom of Core 22 through the bottom of Core 26 .

Diversity and preservation are moderate at this site, and the relative abundance of broken specimens increases toward the top of the studied section. Distephanus crux is dominant in the lowermost two samples and is consistently present up through Sample 604-25-4, $20 \mathrm{~cm}$, but is absent above that level. Similarly, Mesocena circulus and $M$. diodon are consistently present up through Sample 604-25-1, $20 \mathrm{~cm}$; their joint disappearance above $\mathrm{Sec}$ tion 604-25-1 may indicate a disconformity or sharp environmental change. No sample was available from Core 


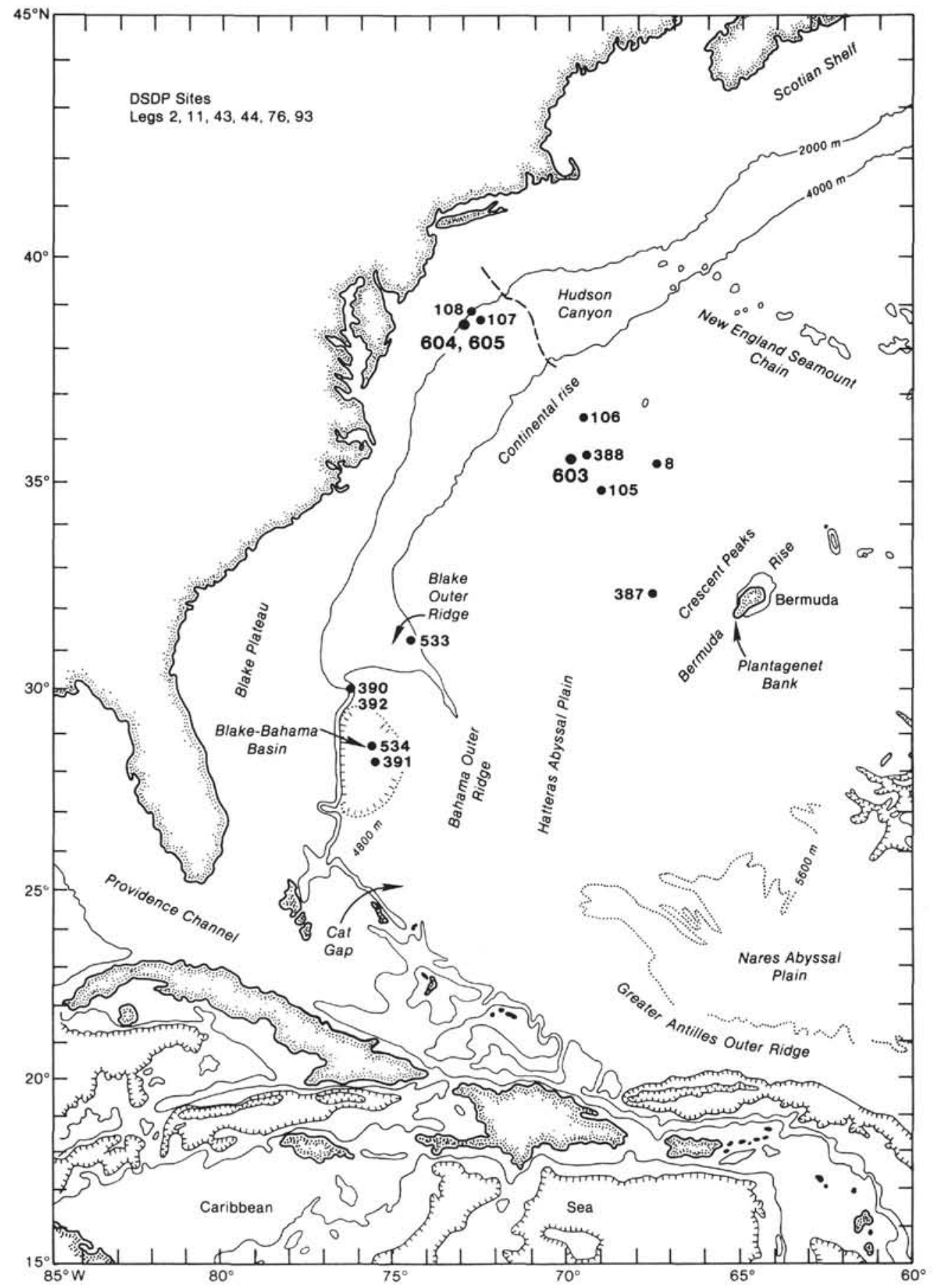

Figure 1. Location of sites drilled on Deep Sea Drilling Project Leg 93.

24 , which recovered little sediment. The cool-water distephanids outnumber the warm-water dictyochids up through Core 25 , but give way in Core 23 to the latter group, which is dominated by Dictyocha brevispina. Throughout the sequence, the asperoid forms of Dictyocha maintain dominance over the fibuloid forms.

Scattered throughout this section are rare Naviculopsis species and other taxa (e.g., Corbisema hastata) that are reworked from Eocene siliceous carbonates. Also noted are rare specimens of $N$. ponticula, reworked from the lower Miocene.
To summarize these observations, the notable local silicoflagellate events in this section seem to be the disappearance of Distephanus crux within Core 604-25, the disappearance of $M$. circulus and $M$. diodon above Core 604-25, and the absence of an obvious asperoid/fibuloid dominance reversal in Dictyocha (unless it occurs near the top of the sample suite, where the numbers of silicoflagellates are too small to provide meaningful data).

According to the zonation proposed by Bukry (1981b) for tropical and subtropical areas, the sample suite would 
Table 1. Silicoflagellate and ebridian studies for the North Atlantic.

\begin{tabular}{|c|c|c|c|c|c|c|c|}
\hline Leg (sites) & 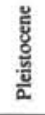 & $\begin{array}{l}\text { हूँ̆ } \\
\frac{8}{2}\end{array}$ & $\begin{array}{l}\text { पू̆ } \\
\frac{\delta}{\Sigma} \\
\frac{8}{\Sigma}\end{array}$ & 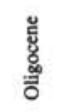 & 苋 & $\begin{array}{l}\text { हूँ } \\
\text { हूँ } \\
\text { है }\end{array}$ & Reference \\
\hline VEMA & & & & & $\mathrm{U}, \mathrm{L}$ & $\mathrm{u}$ & Perch-Nielsen, 1976 \\
\hline Leg $37(332-335)$ & $\mathrm{x}$ & u & u & & & & Bukry, 1977 \\
\hline Leg $38(336-352)$ & $\mathrm{x}$ & $\mathrm{x}$ & $x^{*}$ & $\mathrm{x}^{*}$ & $U^{\bullet}, \mathrm{M}$ & & $\begin{array}{l}\text { Bukry, 1976b } \\
\text { Martini and Müller, } 1976 \\
\text { Perch-Nielsen, } 1978\end{array}$ \\
\hline Leg 39 (354) & & & & $\mathrm{M}^{*}$ & & & Perch-Nielsen, 1977 \\
\hline Leg $41(366-370)$ & & & $\mathrm{L}$ & $U_{, L}$ & & & Bukry, 1978a \\
\hline Leg $43(382-387)$ & & & & $\mathrm{L}$ & $\mathrm{x}$ & $\mathrm{u}$ & Bukry, 1978c \\
\hline Leg $44(388-394)$ & & & M, L & & & & Bukry, 1978b \\
\hline Leg 47 (397) & $\mathrm{x}$ & $\mathrm{u}$ & & & & & Bukry, 1979b \\
\hline Leg $48(399-406)$ & & & L & $\mathrm{U}$ & u & & Bukry, 1985 \\
\hline Leg $49(407-414)$ & $\mathrm{x}$ & $\mathrm{x}$ & $\mathrm{x}$ & $\mathrm{U}, \mathrm{M}$ & & & Martini, 1979 \\
\hline $\begin{array}{l}\text { Leg } 50(415-416) \\
\text { Leg } 78 \text { (541-543) }\end{array}$ & & & $\mathrm{M}_{\mathrm{L}} \mathrm{L}$ & & & & $\begin{array}{l}\text { Bukry, } 1980 \\
\text { Bukry, } 1984\end{array}$ \\
\hline Leg 81 (552-555) & & $\mathbf{L}$ & $\mathrm{U}, \mathrm{L}$ & & M & & Bukry, 1985 \\
\hline
\end{tabular}

Note: All publications listed here have charts showing relative abundances. $\mathrm{X}=$ presen throughout the series; $\mathrm{U}, \mathrm{M}$, or $\mathrm{L}=$ subseries; ${ }^{*}=$ includes ebridian work.

fall within his $D$. brevispina Zone, which extends from the LAD of $C$. triacantha to the asperoid/fibuloid dominance reversal in Dictyocha. Bukry (1981b) tentatively correlates the top of this zone with the lower part of the nannofossil Discoaster quinqueramus Zone, but notes that the reversal of asperoid/fibuloid dominance may be diachronous. At DSDP Site 310 in the northwest Pacific, he found that the asperoid-dominated assemblages ranged from the Pliocene Discoaster tamalis coccolith Subzone to the upper Miocene $D$. berggrenii Subzone, because a cooler environment reduced the anticipated range of Dictyocha fibula. At Site 604, upwelling or the incursion of the Labrador Current, either of which would be accompanied by cooler surface waters, may account for the biosiliceous sediments near the bottom of the section. If this was the case, then the cooler waters may have affected the timing of the dominance reversal among the dictyochids.

In Hole 604, the Miocene/Pliocene boundary is placed at the top of Core 604-25, based on the LAD of the nannofossil Discoaster quinqueramus (Lang and Wise, this volume). This boundary is tentatively placed according to planktonic foraminifers between Sections 3 and 4 of Core 604-23 (Moullade, this volume). It would appear that the dominance reversal among the dictyochids in this region must have occurred after the Miocene, possibly because of cooler water conditions discussed earlier.

Other provincial zonations have been used at higher latitudes. Busen and Wise (1977) have described an upper Miocene Mesocena circulus/M. diodon Zone in the Southern Ocean based on the co-occurrence of those two taxa. The silicoflagellate assemblage they found is very similar to the assemblage at Site 604 , but lacks the abundant Dictyocha brevispina. Their zonation is not applicable for the North American Basin, however, since $\mathrm{Me}$ socena diodon occurs earlier (middle Miocene) in these middle latitudes (Bukry, 1978c) than it does at the Southern Ocean Sites 328 and 329. For this reason, in sediments of similar age and even $18^{\circ}$ latitude farther north, Bukry (1985) has found it necessary to use the low-latitude zonation in this area.

\section{Site 605 (Table 3)}

Hole $605\left(38^{\circ} 44.53^{\prime} \mathrm{N}\right.$; $72^{\circ} 36.55^{\prime} \mathrm{W}$; water depth, $2197 \mathrm{~m}$ ), drilled $5 \mathrm{~km}$ landward of Hole 604, recovered about $150 \mathrm{~m}$ of siliceous nannofossil chalk (lithostratigraphic Unit III; see Site 604-605 chapter, this volume) with good preservation of silicoflagellates and ebridians and high diversity. The section is early middle Eocene in age.

The distribution of silicoflagellates and ebridians is plotted in Table 3 for 23 samples from this thick middle Eocene section. The most striking aspect of the populations is the fact that the total ebridians outnumber the total silicoflagellates in all but two samples. In Sample $605-17-3,20 \mathrm{~cm}$, they exceed the silicoflagellates by an order of magnitude. This is in strong contrast to the Miocene of Site 604 , where the ebridians comprise a minor part of the total siliceous population. We can offer no explanation for the preponderance of ebridians in the Eocene section.

The silicoflagellate assemblage is dominated by Corbisema triacantha and Naviculopsis foliacea. It can be assigned to the $N$. foliacea Zone, which Bukry (1981b) correlates with a long interval from the coccolith lower Eocene Tribrachiatus orthostylus Zone to within the Coccolithus staurion Subzone of the middle Eocene Nannotetrina quadrata Zone.

There is little stratigraphic variation within the silicoflagellate assemblage at Site 605 . Two isolated specimens of Dictyocha spinosa in Cores 605-14 and 605-16 suggest that the assemblage can be assigned to the subzone of the same name defined by Bukry (1978b). The rarity of the species in this section does not make it a viable marker in this locality.

Lithostratigraphic Unit III is assigned to the coccolith Chiasmolithus gigas and Discoaster strictus subzones of the Nannotetrina quadrata Zone (Applegate and Wise, this volume). According to Bukry (1981b), that interval is well within the limits of the silicoflagellate Dictyocha spinosa Subzone.

\section{COMMENT ON SILICOFLAGELLATE TAXONOMY}

A major limitation upon the usefulness of silicoflagellates has been the great confusion concerning the biological validity of the various taxa. Silicoflagellates are marked by a wide diversity of skeletal shapes. Paleontologists, in particular, have described a great many species on the basis of the number of skeletal sides, types and dimensions of the apical structures, or the prominence of the basal spines, accessory spines, or surface ornamentation. Whereas the paleontologic literature has lengthy floral listings, investigators working with recent forms (Hovasse, 1946; Frenguelli, 1935; Poelchau, 1974, 1976) have emphasized the variation within populations. Van Valkenburg and Norris (1970) have found within a single clonal culture silicoflagellate skeletal shapes representing, if judged by the traditional taxonomy, three different genera. Furthermore, several investigators (Gemeinhardt, 1930; Bukry and Foster, 1973) have described 
K. MCCARTNEY, S. W. WISE, JR.

Table 2. Late Miocene silicoflagellates and ebridians from DSDP Site 604, Cores 22-26.

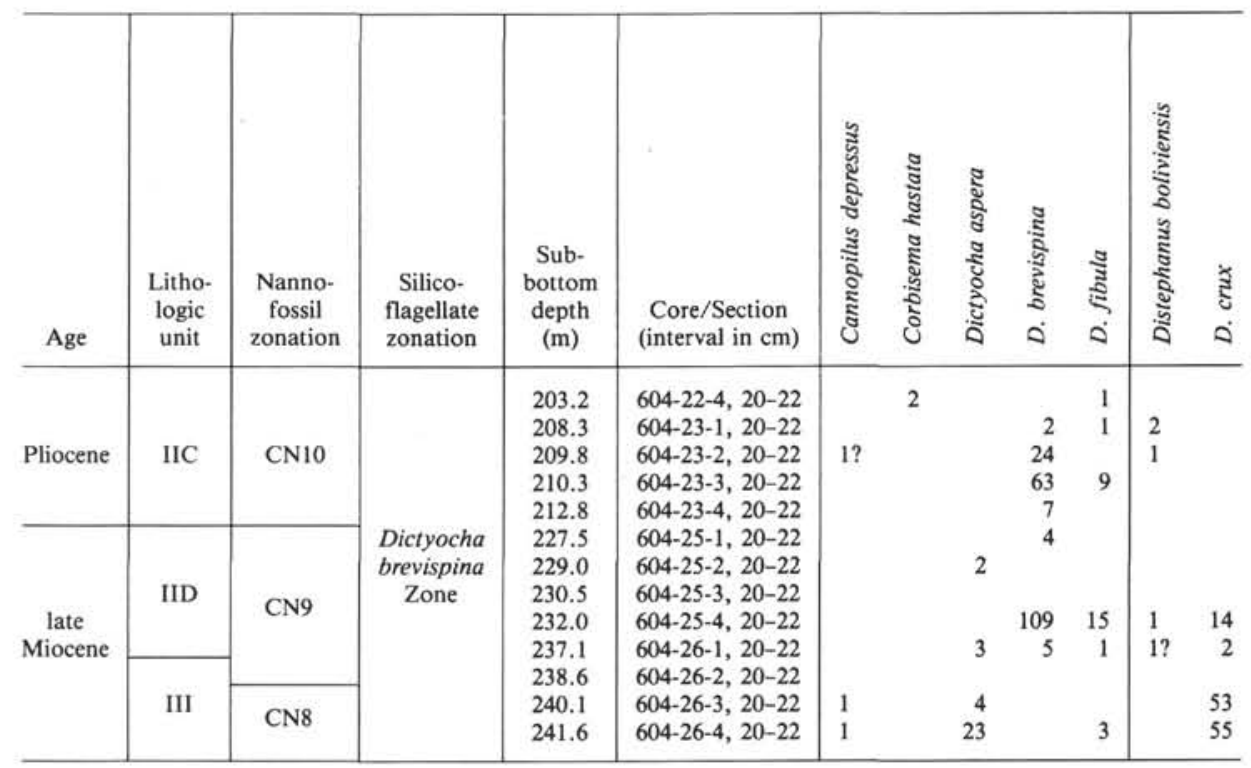

Note: Specimens are recorded as total no. found for no. of $22 \times 40 \mathrm{~mm}$ slides examined.

double skeleton sets from a single cell in which each of the two silicoflagellate skeletons represents a different genus. Van Valkenburg $(1970,1980)$ states that many biologists believe that the current diversity of silicoflagellate skeletal shapes represent only two living species, Dictyocha fibula and $D$. octonaria.

Paleontologists, however, frequently see relatively minor differences in silicoflagellate shape as representing different species, and a complex taxonomy has resulted. The senior author questions the biologic validity of much of this taxonomy, but until there is a better understanding of the factors that control silicoflagellate shape and the relationship of the various shapes to each other, the current taxonomy must be maintained. The current taxonomy, with taxonomic names for all of the variations of silicoflagellate shape, may provide clues toward solving problems relating to silicoflagellate skeletal morphology. Efforts should be made to make distinctions between minor variations in morphology. Descriptive terms such as "cruxoid" or "medusoid" are important in that they draw attention to distinct skeletal shapes. To simply "lump" these distinct shapes in with the taxa to which they are closely related, without drawing attention to their relative abundance, causes a loss of information that may later be valuable.

\section{SYSTEMATIC PALEONTOLOGY}

To save time and space the synonomies include only the first description and, if needed, a recent reference that has a more complete taxonomy.

Silicoflagellates

\section{Genus CANNOPILUS Haeckel, 1887}

Cannopilus depressus (Ehrenberg)

Halicalyptra depressa Ehrenberg, 1854, pl. 18, fig. 111.

Remarks. The rare specimens found in this study may have been reworked from strata lower in the Miocene.

\section{Genus CORBISEMA Hanna, 1928 \\ Corbisema apiculata (Lemmermann) \\ (Plate 1, Fig. 10)}

Dictyocha triacantha var. apiculata Lemmermann, 1901, p. 259, pl. 10, figs. $19,20$.

Corbisema apiculata (Lemmermann) Ling, 1972, p. 153, pl. 24, fig. 1.

Remarks. This species was found to vary in size, outline, and the position and size of the sustaining spines. The most common form has basal spines of moderate length and large sustaining spines that are directed obliquely. Specimens were usually twice the size of associated Corbisema triacantha.

Bukry (1978c) found C. apiculata in the middle Eocene of Site 386.

\section{Corbisema bimucronata Deflandre \\ (Plate 1, Fig. 9)}

Corbisema bimucronata Deflandre, 1950, p. 191, figs. 174-177.

Remarks. This species is sporadic in the middle Eocene samples of Site 605 .

\section{Corbisema hastata (Lemmermann)}

Corbisema triacantha var. hastata Lemmermann, 1901, p. 259, pl. 10, fig. 16,17 .

Corbisema hastata (Lemmermann), Ling, 1972, p. 155, pl. 24, fig. 5.

Remarks. Specimens of $C$. hastata, belonging to several subspecies, were found sporadically in the middle Eocene of Site 605 and in a single sample of Site 604 .

\section{Corbisema inermis inermis (Lemmermann)} (Plate 1, Figs. 13-16)

Dictyocha triacantha var. inermis Lemmermann, 1901, p. 259, pl. 10, fig. 21.

Corbisema inermis inermis (Lemmermann), Bukry, 1976a, p. 892.

Remarks. $C$. inermis inermis is characterized by a generally large size, narrow apical struts, and a lack of spines. Some of the specimens in this study were somewhat pointed at the corners of the basal ring. This species was uncommon, but present, throughout the middle Eocene interval of Site 605 .

\section{Corbisema recta (Schulz)}

(Plate 1, Figs. 11, 12)

Dictyocha triacantha var. recta Schulz, 1928, p. 250, fig. 32a, b. Corbisema recta (Schulz), Ling, 1972, p. 155, pl. 24, figs. 6, 7. 
Table 2 (continued).

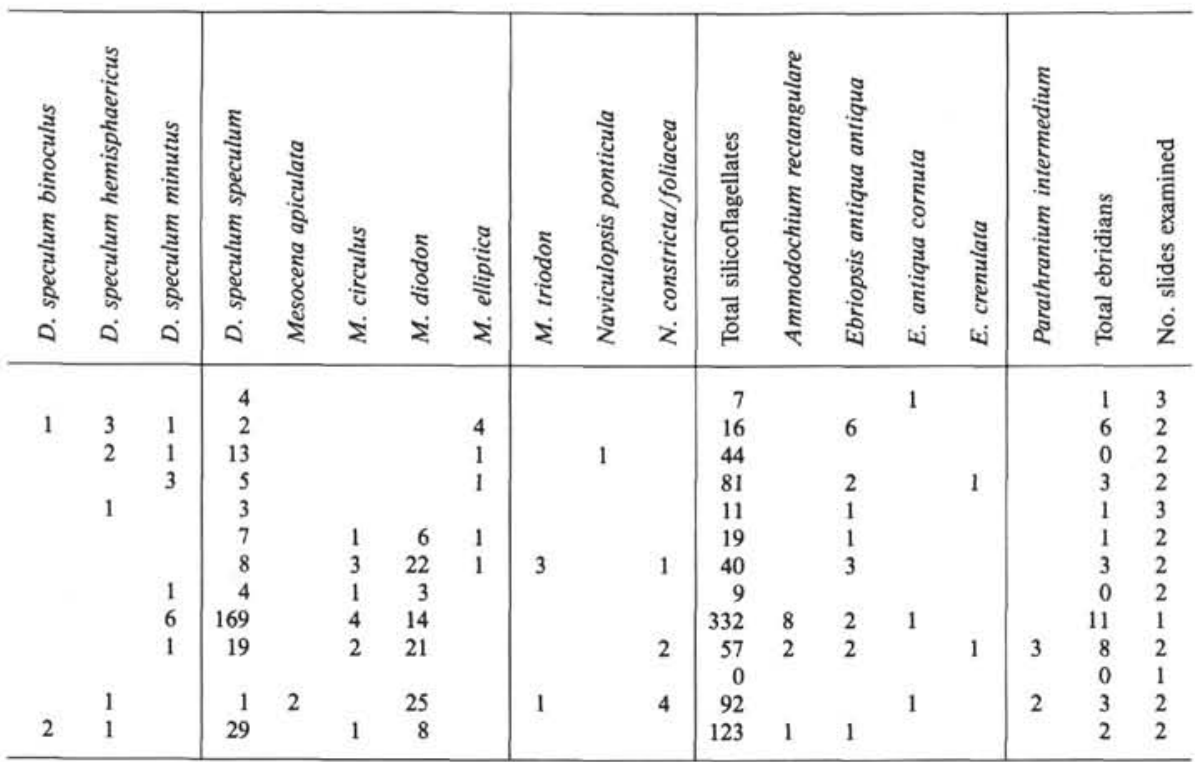

Table 3. Eocene silicoflagellates and ebridians from DSDP Site 605 , Cores 7 to 21 .

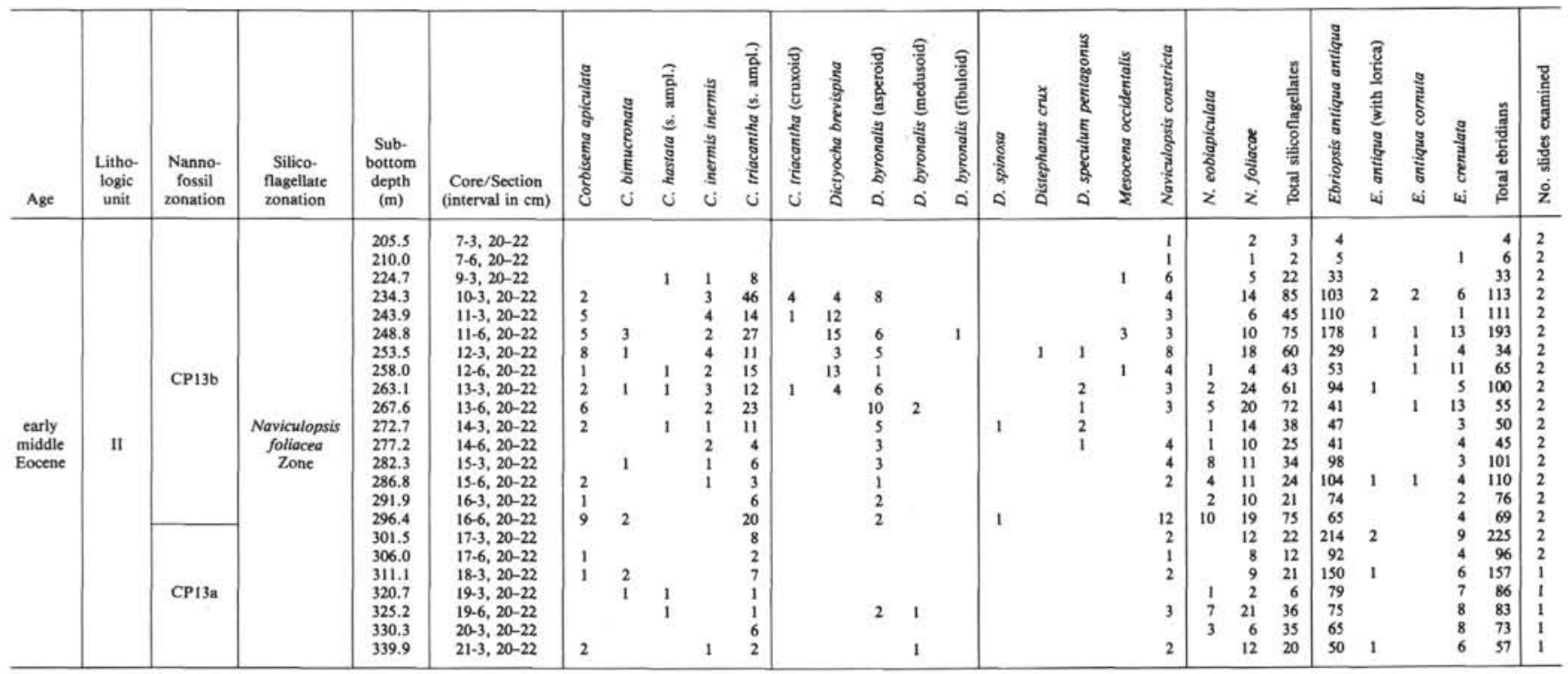

Note: Specimens are recorded as total no. found for no. of $22 \times 40 \mathrm{~mm}$ slides examined.

Corbisema triacantha (Ehrenberg)

(Plate 1, Figs. 1-5, 7, 8)

Dictyocha triacantha Ehrenberg, 1844, p. 80.

Corbisema triacantha (Ehrenberg), Busen and Wise, 1977, p. 713.

Remarks. Although the size of all specimens is very consistent, about $40 \mu \mathrm{m}$ across the side of the basal ring, there is considerable variation in the shape of the basal ring, the length of the spines, and the nature of the apical strut intersection. Bukry $(1977,1978 \mathrm{~b})$ and Ling (1972) have described several subspecies, but the specimens of this study did not fall into distinct taxa. Both C. triacantha concava and C. triacantha triacantha were well represented, but intermediates between those extremes were also common. Both types were occasionally found to have offset apical struts, as in C. triacantha mediana. Some specimens have the characteristics of two or all three of these subspecies. Rare specimens were found to have cruxoid openings in the apical strut intersection (Plate 1, Figs. 3, 8). Since division into subspecies was often difficult, and in the studied intervals had no apparent stratigraphic importance, all forms were simply counted as C. triacantha.

\section{Genus DICTYOCHA Ehrenberg, 1837}

\section{Dictyocha aspera aspera (Lemmermann)}

(Plate 3, Fig. 1)

Dictyocha fibula var. aspera Lemmermann, 1901, p. 260, pl. 10, figs. 27, 28.

Dictyocha aspera aspera (Lemmermann), Bukry, 1983, p. 329.

Remarks. $D$. aspera aspera is characterized by a bar that is parallel to the minor axis but has a shorter apical bar and a more rhomboidshaped basal ring than $D$. brevispina. The bar is not inclined with respect to the minor axis. This species occurs sporadically below Core 24 of Site 604 .

\section{Dictyocha brevispina (Lemmermann)}

(Plate 3, Figs. 2, 3, 8-10)

Dictyocha fibula var. brevispina Lemmermann, 1901, p. 260. Dictyocha brevispina (Lemmermann), Bukry, 1976c, p. 723. 
Remarks. $D$. brevispina has a longer apical bar and strut positions closer to the minor axis than $D$. aspera. This causes smaller minor-axis portals. The strut position closer to the minor axis causes less constraint on the rest of the basal ring, which bulges outward toward the major axis, causing an overall elliptical shape instead of the rhomboid shape usually found when the struts are more centered, as in $D$. aspera and $D$. fibula. The length of the apical bar varied a great deal, from 40 to nearly $100 \%$ of the internal diameter of the minor axis.

As one moves up the section in the silicoflagellate-bearing interval of Site 604, the bar length progressively increases, changing from forms similar to $D$. aspera (Pl. 3, Fig. 1, Section 604-26-4), to forms approaching $D$. transversa (Pl. 3, Figs. 9 and 10, Section 604-23-1). The change appears to be gradual, making identification of some forms difficult.

\section{Dictyocha byronalis Bukry}

(Plate 3, Figs. 4-7, 11)

Dictyocha byronalis Bukry in Barron et al., 1984, p. 151, pl. 3, figs. $1-4$.

Remarks. $D$. byronalis is a robust form with relatively long major spines and an inclined, generally asperoid, bar. The bar is highly arched above the plane of the basal ring. Rare medusoid (PI. 3, Fig. 7) and fibuloid (Pl. 3, Fig. 11) forms were found which, because of similarities in the shape, size, thickness of the struts, and the amount of arch of the apical bar, were counted as members of this taxon. D. byronalis was found throughout most of the silicoflagellate-bearing interval of Site 605 .

\section{Dictyocha fibula Ehrenberg}

Dictyocha fibula Ehrenberg, 1839, fide Loeblich et al., 1968, p. 90, pl. 9, figs. 9-12.

Dictyocha fibula Ehrenberg, Bukry and Foster, 1973, pp. 826-827.

Remarks. The authors use a broad interpretation of this taxa. All dictyochids with vertically oriented apical bars were counted as $D$. fibula. D. fibula occurs sporadically throughout the silicoflagellatebearing interval of Site 604 .

\section{Dictyocha spinosa (Deflandre)}

(Plate 1, Fig. 6)

Corbisema spinosa Deflandre, 1950, p. 193, figs. 178-182.

Dictyocha spinosa (Deflandre) Glezer, 1966, p. 238, pl. 10, figs. 6-8.

Remarks. Dictyocha spinosa differs from Corbisema hexacantha in having only three of the six spines in the plane of the basal ring. The two taxa exist concurrently, though $D$. spinosa appears earlier and disappears later than $C$. hexacantha, and are frequently found together (Bukry, 1976a, c; Bukry and Foster, 1974; Barron et al., 1984). Their morphologic, stratigraphic, and geographic similarities may indicate an evolutionary relationship.

\section{Genus DISTEPHANUS Stohr, 1880 \\ Distephanus boliviensis (Frenguelli)}

(Plate 2, Figs. 1, 4)

Dictyocha boliviensis Frenguelli, 1940 (in part), p. 44, fig. 4.

Remarks. $D$. boliviensis differs from $D$. speculum in being larger and having equant distal spines. In this study, $D$. boliviensis was about twice the size of specimens of $D$. speculum speculum in the same samples. Few specimens were found, but fragments, particularly in the top of the Site 604 interval, were more common. Specimens with both six and seven distal spines were found.

\section{Distephanus crux (Ehrenberg)}

(Plate 2, Fig. 9, 11)

Distephanus crux Ehrenberg, 1840, p. 207; Ehrenberg, 1854, pl. 18, fig. 56, pl. 33(XV), fig. 9.

Remarks. D. crux occurred only in the bottom section of Core 25 and throughout Core 26 of Site 604. The size of the specimens (about $65 \mu \mathrm{m}$ ) was similar to associated $D$. speculum speculum.

\section{Distephanus speculum binoculus (Ehrenberg)}

(Plate 2, Fig. 6)

Dictyocha binoculus Ehrenberg, 1844, p. 63, 79.

Distephanus speculum binoculus (Ehrenberg), Bukry, 1975, p. 854.

\section{Distephanus speculum hemisphaericus (Ehrenberg)}

(Plate 2, Figs. 3, 5)

Dictyocha hemisphaerica Ehrenberg, 1844, pl. 17, fig. 5 .

Distephanus speculum hemisphaericus (Ehrenberg), Bukry, 1975, p. 854.

Remarks. D. speculum hemisphaericus is here considered to be any Distephanus with three or more apical openings and the basal ring and distal spines characteristic of Distephanus speculum - that is, with two opposing spines larger than the other spines. Bukry (1975) differentiated $D$. speculum hemisphaericus from $D$. boliviensis major by the presence of rounded rather than angular apical openings. Although the specimens in this study generally had angular apical openings, the nature of the basal ring and distal spines showed an affinity much closer to Distephanus speculum than to $D$. boliviensis.

\section{Distephanus speculum minutus (Bachmann) \\ (Plate 2, Fig. 7)}

Dictyocha speculum f. minuta Bachmann in Ichikawa et al., 1967, p. 161 , pl. 7, figs. $12-15$.

Remarks. Bukry (1981a) distinguished this subspecies from D. speculum speculum by a larger apical ring whose inner diameter is at least $50 \%$ of the inner diameter of the basal ring. This taxon is most common in the higher latitudes (Bukry, 1973). Specimens were present, but not common, through most of the silicoflagellate-bearing interval of Site 604. Specimens of $D$. speculum minutus were consistently smaller than most $D$. speculum speculum associated in the same samples. The distance between major spine tips was usually about $40 \mu \mathrm{m}$.

\section{Distephanus speculum pentagonus Lemmermann} (Plate 2, Fig. 8)

Distephanus speculum var. pentagonus Lemmermann, 1901, p. 264, pl. 11, fig. 19.

Distephanus speculum pentagonus Lemmermann, Bukry, 1976a, p. 895.

Remarks. Specimens were found in a three-core interval in the middle Eocene of Site 605. This extends the known range of this subspecies, which had first been observed in upper Oligocene sediments (Bukry, 1975, 1976a). Their abundance, though they are by no means common, and the absence of D. speculum speculum and other younger fossils indicates that this occurrence might not be the result of downhole contamination.

\section{Distephanus speculum speculum (Ehrenberg)} (Plate 2, Fig. 2)

Dictyocha speculum Ehrenberg, 1839, p. 150; Ehrenberg, 1854, pl. 18, fig. 57 ; pl. 19, fig. 41 ; pl. 21, fig. 44 ; pl. 22, fig. 47.

Remarks. Distephanus speculum speculum in this study varied greatly in size but very little in morphology. The two major spines had lengths that together approximately equaled the length of the basal ring. The other spines were about half the length of the major spines. There was very little variation on this pattern. The apical apparatus was usually highly arched above the plane of the basal ring. Lengths, measured as the distance between major spine tips, ranged from 40 to $100 \mu \mathrm{m}$.

\section{Genus MESOCENA Ehrenberg, 1839}

Remarks. For this report all silicoflagellates not having an apical apparatus are assigned to Genus Mesocena.

\section{Mesocena apiculata Schulz \\ (Plate 4, Fig. 8)}

Mesocena oamaruensis apiculata Schulz, 1928, p. 240, fig. 11. Mesocena apiculata (Schulz), Ling, 1972, p. 173, pl. 28, figs. 2-4.

Remarks. Two specimens were found in Section 604-26-3. Since the known range of Mesocena apiculata extends only to the early Miocene, these are probably reworked.

\section{Mesocena circulus (Ehrenberg)}

(Plate 4, Fig. 7)

Mesocena circulus (Ehrenberg) Ehrenberg, 1844, p. 65. 


\section{Mesocena diodon Ehrenberg}

(Plate 4, Figs. 5, 6)

Mesocena diodon Ehrenberg, 1844, p. 71, 84.

Remarks. Both smooth and nodose forms of Mesocena diodon were found, with the smooth forms predominating. Aberrant forms were more common in this species than in any other in this chapter, making up almost $10 \%$ of all specimens seen (this value includes three-spined forms counted as $M$. triodon). Size was usually about $75 \mu \mathrm{m}$.

\section{Mesocena elliptica (Ehrenberg)}

(Plate 4, Fig. 9)

Dictyocha (Mesocena) elliptica Ehrenberg, 1840, p. 208; Ehrenberg, 1854 , pl. 20 (1), fig. 44 a, b.

Mesocena elliptica (Ehrenberg), Bukry, 1978b, p. 819.

\section{Mesocena occidentalis Hanna ex Bukry}

Mesocena occidentalis Hanna, 1931, p. 200, pl. E, fig. 1.

Mesocena occidentalis Hanna ex Bukry, 1977, p. 834.

Remarks. Mesocena occidentalis has a quadrangular basal ring with relatively long spines at each corner. It differs from $M$. elliptica in being diamond-shaped in outline rather than elliptical, and in having longer spines. $M$. occidentalis was only rarely found in the middle Eocene of Site 605 .

\section{Mesocena triodon Bukry}

(Plate 4, Figs. 1-4)

Mesocena triodon Bukry, 1978b, pp. 819-820.

Remarks. Three-spined mesocenids were occasionally found. These had somewhat elliptic basal rings with two major spines at opposing ends of the major axis. The third spine was smaller and its position varied. These were associated with specimens of $M$. diodon of similar size and appearance, indicating that the type may be an aberrant variety of $M$. diodon rather than a separate species.

\section{Genus NAVICULOPSIS Frenguelli, 1940 \\ Naviculopsis constricta (Schulz) \\ (Plate 5, Figs. 3, 4)}

Dictyocha navicula biapiculata constricta Schulz, 1928, p. 246, fig. 21. Naviculopsis constricta (Schulz), Bukry, 1975, p. 856.

Remarks. $N$. constricta has larger portals and a narrower band than $N$. foliacea. The width of the band was usually equal to half the width of the basal ring, though specimens with wider bands, sometimes approaching $N$. foliacea, were seen.

\section{Naviculopsis eobiapiculata Bukry}

(Plate 5, Figs. 5-8)

Naviculopsis eobiapiculata Bukry, 1978c, p. 878.

Remarks. $N$. eobiapiculata is distinguished by its highly arched band, which is of constant width until the band is in close proximity to the ring (see Fig. 2). Although this species is easy to identify when the specimen is tilted (as shown in Plate 5, Fig. 4), it can be difficult to distinguish from $N$. constricta when it is lying flat on its basal ring. Naviculopsis eobiapiculata, however, usually is slightly smaller and wider than $N$. constricta and the margins of the band are straight and parallel until very close to the basal ring.

\section{Naviculopsis foliacea Deflandre}

(Plate 5, Figs, 1-2)

Naviculopsis foliacea Deflandre, 1950, p. 204, figs. 235-240.

Remarks. This species has moderately sized elliptical portals and a wide band with concave margins. In this study there was much variation in band width, which was between 25 and $50 \%$ of the internal length of the basal ring.

\section{Naviculopsis ponticula Ehrenberg}

(Plate 5, Fig. 9)

Dictyocha ponticulus Ehrenberg, 1844, p. 258, 267; Bailey, 1845, pl. 4, fig. 21.

Naviculopsis ponticula (Ehrenberg), Bukry, 1978b, p. 821.
A
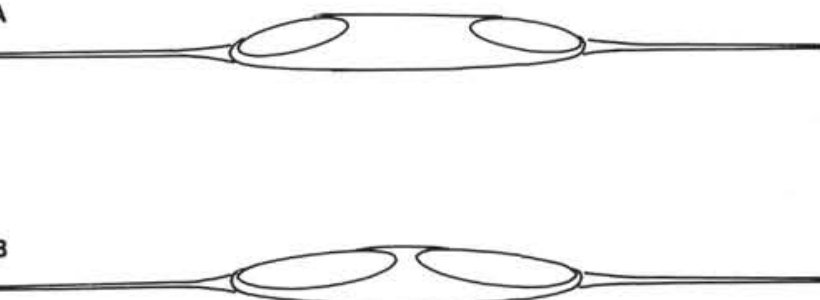

c

Figure 2. Drawings of three Naviculopsis species. View is slightly tilted with respect to both the major and the minor axes. A. Naviculopsis foliacea. B. Naviculopsis constricta. C. Naviculopsis eobiapiculata.

Remarks. One specimen was found in Section 604-23-2. This is above the known extinction of Naviculopsis and therefore the specimen is probably reworked from lower Miocene strata.

Ebridian Taxonomy

\section{Genus AMMODOCHIUM Hovasse, 1932 \\ Ammodochium rectangulare (Schulz) \\ (Plate 5, Fig. 15)}

Ebria antiqua var. rectangularis Schulz, 1928, p. 274, fig. 72 a-d. Ammodochium rectangulare (Schulz), Ling, 1971, p. 694.

Remarks. Ammodochium rectangulare was found in Section 60425-4 and through Core 604-26.

\section{Genus EBRIOPSIS Hovasse, 1932 \\ Ebriopsis antiqua antiqua (Schulz) \\ (Plate 5, Fig. 10)}

Ebria antiqua Schulz, 1928 (in part), pp. 273, 274, fig. 696. Ebriopsis antiqua antiqua (Schulz), Ling, 1977, p. 215, pl. 17, 18.

Remarks. This species was very abundant throughout the siliceous interval of Site 605 (it was, in fact, generally more common than the sum of all silicoflagellate taxa), and was generally present throughout the siliceous interval of Site 604. Specimens of Ebriopsis antiqua anti$q u a$ and $E$. crenulata were of similar size and some specimens were found that appeared to be intermediates between the two. Specimens of E. antiqua with lorica are tabulated separately.

\section{Ebriopsis antiqua cornuta Ling (Plate 5, Fig. 17)}

Ebriopsis cornuta Dumitrică and Perch-Nielsen, in Perch-Nielsen, 1975, p. 880 , fig. 2 , pl. 7 .

Ebriopsis antiqua cornuta Ling, 1977, p. 215, pl. 3, figs. 19-22.

\section{Ebriopsis crenulata Hovasse}

(Plate 5, Fig. 11)

Ebriopsis crenulata Hovasse, 1932b, p.281, fig. 4 I, II.

Remarks. Ebriopsis crenulata was distinguished from $E$. antiqua antiqua by its coarsely crenulated surface ornamentation.

\section{Genus PARATHRANIUM Hovasse, 1932}

Parathranium tenuipes (Hovasse)

(Plate 5, Figs. 14, 16)

Thranium tenuipes Hovasse, 1932a, p. 123, fig. 5.

Parathranium tenuipes (Hovasse), Ling, 1972, pp. 198-199. 
Remarks. Five specimens of Parathranium tenuipes were found in Core 26 of Site 604 . This species differs from $P$. intermedium in having relatively thinner skeletal elements (Ling and McPherson, 1974).

\section{ACKNOWLEDGMENTS}

We thank Paul F. Ciesielski, David Bukry, Hsin-Yi Ling, and Louis Tesar for their comments. Laboratory support was provided by NSF Grant DPP-8414268 and a Grant-in-Aid from Sigma Xi, The Scientific Research Society. We would like to thank the Deep Sea Drilling Project for providing samples from other legs for comparative study with the Leg 93 material.

\section{REFERENCES}

Abbott, W. H., 1978. Correlation and zonation of Miocene strata along the Atlantic margin of North America using diatoms and silicoflagellates. Mar. Micropaleontol., 3:15-34.

1980. Diatoms and stratigraphically significant silicoflagellates from the Atlantic Margin Coring Project and other Atlantic Margin sites. Micropaleontology, 26:49-80.

Abbott, W. H., and Ernissee, J. J., 1983. Biostratigraphy and paleoecology of the Diatomaceous Clay Unit in the Miocene Pungo River Formation of Beaufort County, North Carolina. In Ray, C. E. (Ed.), Geology and Paleontology of the Lee Creek Mine, North Caroline, Part I. Smithsonian Contrib. Paleobiol., No. 53:287-353.

Bailey, J. W., 1845. Notice of some new localities of Infusoria, fossil and Recent. Am. J. Sci., 48:321-343.

Barron, J. A., Bukry, D., and Poore, R. Z., 1984. Correlation of the middle Eocene Kellogg Shale of northern California. Micropaleontology, 30:138-170.

Bukry, D., 1973. Coccoliths and silicoflagellates from Deep Sea Drilling Project Leg 19, North Pacific Ocean and Bering Sea. In Creager, J. S., Scholl, D. W., et al., Init. Repts. DSDP, 19: Washington (U.S. Govt. Printing Office), 857-867.

1975. Silicoflagellate and coccolith stratigraphy, Deep Sea Drilling Project Leg 29. In Kennett, J. P., Houtz, R. E. et al., Init. Repts. DSDP, 29: Washington (U.S. Govt. Printing Office), 845872.

1976a. Cenozoic silicoflagellate and coccolith stratigraphy, South Atlantic Ocean, Deep Sea Drilling Project Leg 36. In Hollister, C. D., Craddock, C., et al., Init. Repts. DSDP, 35: Washington (U.S. Govt. Printing Office), 885-917.

1976b. Silicoflagellate and coccolith stratigraphy, Norwegian-Greenland Sea, Deep Sea Drilling Project Leg 38. In Talwani, M., Udintsev, G., et al., Init. Repts. DSDP, 38: Washington (U.S. Govt. Printing Office), 843-856.

1976c. Silicoflagellate and coccolith stratigraphy, southeastern Pacific Ocean, Deep Sea Drilling Project Leg 34. In Yeats, R. S., Hart, S. R., et al., Init. Repts. DSDP, 34: Washington (U.S. Govt. Printing Office), 715-735.

1977. Coccolith and silicoflagellate stratigraphy, South Atlantic Ocean, Deep Sea Drilling Project Leg 39. In Supko, P. R., Perch-Nielsen, K., et al., Init. Repts. DSDP, 39: Washington (U.S. Govt. Printing Office), 825-840.

1978a. Cenozoic coccolith and silicoflagellate stratigraphy, offshore northwest Africa, Deep Sea Drilling Project Leg 41. In Lancelot, Y., Seibold, E., et al., Init. Repts. DSDP, 41: Washington (U.S. Govt. Printing Office), 689-707.

1978b. Cenozoic coccolith, silicoflagellate, and diatom stratigraphy, Deep Sea Drilling Project Leg 44. In Benson, W. E., Sheridan, R. E., et al., Init. Repts. DSDP, 44: Washington (U.S. Govt. Printing Office), 807-863.

1978c. Cenozoic silicoflagellate and coccolith stratigraphy, northwestern Atlantic Ocean, Deep Sea Drilling Project Leg 43. In Benson, W. E., Sheridan, R. E., et al., Init. Repts. DSDP, 44: Washington (U.S. Govt. Printing Office), 775-805.

1979a. Coccolith and silicoflagellate stratigraphy, northern Mid-Atlantic Ridge and Reykjanes Ridge, Deep Sea Drilling Project Leg 49. In Luyendyk, B. P., Cann, J. R., et al., Init. Repts. $D S D P$, 49: Washington (U.S. Govt. Printing Office), 551-582.

$1979 \mathrm{~b}$. Comments on opal phytoliths and stratigraphy of Neogene silicoflagellates and coccoliths at Deep Sea Drilling Project Site 397 off Northwest Africa. In Luyendyk, B. P., Cann, J. R., et al., Init. Repts. DSDP, 49: Washington (U.S. Govt. Printing Office), 977-1010.
1980. Miocene Corbisema triacantha Zone phytoplankton from Deep Sea Drilling Project Sites 415 and 416, off Northwest Africa. In Lancelot, Y., Winterer, E. L., et al., Init. Repts. DSDP, 50: Washington (U.S. Govt. Printing Office), 507-523.

1981a. Silicoflagellate stratigraphy of offshore California and Baja California, Deep Sea Drilling Project Leg 63. In Yeats, R. S., Haq, B. U., et al., Init. Repts. DSDP, 63: Washington (U.S. Govt. Printing Office), 539-557.

$1981 \mathrm{~b}$. Synthesis of silicoflagellate stratigraphy for Maestrichtian to Quaternary marine sediment. In Warme, J. E., Douglas, R. G., and Winterer, E. L. (Eds.), The Deep Sea Drilling Project: A Decade of Progress. Soc. Econ. Paleontol. Mineral. Spec. Publ., 32:433-444.

1983. Upper Cenozoic silicoflagellates from offshore Ecuador, Deep Sea Drilling Project Site 504. In Cann, J. R., Langseth, M .G., Honnorez, J., Von Herzen, R. P., White, S. M., et al., Init. Repts. DSDP, 69: Washington (U.S. Govt. Printing Office), 321342 .

1984. Neogene silicoflagellates from Deep Sea Drilling Project Site 543, Western Tropical Atlantic Ocean. In Biju-Duval, B. Moore, J. C., et al., Init. Repts. DSDP, 78A: Washington (U.S. Govt. Printing Office), 463-468.

1985. Cenozoic silicoflagellates from Rockall Plateau, Deep Sea Drilling Project Leg 81. In Roberts, D. G., Schnitker, D., et al., Init. Repts. DSDP, 81: Washington (U.S. Govt. Printing Office), 547-563.

Bukry, D., and Foster, J. H., 1973. Silicoflagellate and diatom stratigraphy, Leg 16, Deep Sea Drilling Project. In van Andel, T. H., Heath, G. R., et al., Init. Repts. DSDP, 16: Washington (U.S. Govt. Printing Office), 815-871.

1974. Silicoflagellate zonation of Upper Cretaceous to lower Miocene deep-sea sediment. U.S. Geol. Surv. J. Res., 2:303-310.

Busen, K. E., and Wise, S. W., Jr., 1977. Silicoflagellate stratigraphy, Deep Sea Drilling Project, Leg 36. In Barker, P. F., Dalziel, I. W. D., et al., Init. Repts. DSDP, 36: Washington (U.S. Govt. Printing Office), 697-743.

Deflandre, G., 1950. Contribution a l'étude des silicoflagellidés actuels et fossiles. Microscopie, 2:72-108, 117-142, and 191-210.

Ehrenberg, C. G., 1839. Uber die Bildung der Kreidefelsen und des Kreidemergels durch unsichtbäre Organismen. K. Preuss. Akad. Wiss. Berlin Ber., Jahrg. 1838, pp. 59-148.

1840. 274 Blätter von ihm selbst augeführter Zeichnungen von ebenso vielen Arten. K. Preuss Akad. Wiss. Berlin Ber., Jahrg. 1840 , pp. 197-219.

1844. Mittheilung über zwei neue Lager von Gebirgsmassen aus Infusorien als Meeres-Absatz in Nord-Amerika und eine Vergleichung derselben mit den organischen Kreide-Gebilden in Europa und Afrika. K. Preuss. Akad. Wiss. Berlin Ber., Jahrg. 1844, pp. 57-97.

1854. Mikrogeologie: Leipzig (Leopold Voss).

Ernissee, J. J., Abbott, W. H., and Huddlestun, P. F., 1977. Microfossil correlation of the Coosawhatchie Clay (Hawthorn Formation, Miocene) of South Carolina, and its equivalent in Georgia. Mar. Micropaleontol., 2:105-119.

Frenguelli, J., 1935. Variaciones de Dictyocha fibula en el Golfo de San Matias. An. Mus. Argent. Cient. Nat., 38:263-381.

1940. Consideraciones sobre los silicoflagelados fósiles. Mus. La Plata Rev., Paleontol., 2:37-112.

Gemeinhardt, K., 1930. Silicoflagellatae. In Rabenhorst, L., (Ed.), Kryptogamen-Flora von Deutschland, Osterreich und der Schweiz: Leipzig (Akad. Verlagsgesellschaft), 10:1-87.

Glezer, Z. I., 1966. Silicoflagellatophyceae. In Gollerbakh, M. M. (Ed.), Cryptogamic Plants of the U.S.S.R. (Vol. 7). V. A. Komarova Bot. Inst., 1-363. (Transl. from Russian by Israel Program for Scientific Translations Ltd., Jerusalem, 1970.)

Hanna, G. D., 1931. Diatoms and silicoflagellates of the Kreyenhagen shale. Calif. Div. Mines Geol. State Mineral. Rep., 27:187-201.

Hovasse, R., 1932a. Note preliminaire sur les Ébriacées. Soc. Zool. France Bull., 57:118-131.

1932b. Second note sur les Ebriacées. Soc. Zool. France Bull., 57:278-283.

1946. Flagellés à squelette silicieux. Silicoflagellés et Ebridés provenant du plancton recueilli au cours des campagnes scientifiques de Prince Albert I de Monaco (1885-1912). Res. Campagnes Sci., 107. 
Ichikawa, W., Shimizu, I., and Bachmann, A., 1967. Fossil silicoflagellates and their associated uncertain forms in Iida Diatomite, Noto Peninsula, Central Japan. Sci. Rep. Kanazawa Univ., 12:143172.

Laws, R. A., 1983. Preparing strewn slides for quantitative microscopical analysis: A test using calibrated microspheres. Micropaleontology, 29:60-65.

Lemmermann, E., 1901. Silicoflagellatae. D. Bot. Ges. Ber., 19:247271.

Ling, H. Y., 1971. Silicoflagellates and ebridians from the Shinzan diatomaceous mudstone member of the Onnagawa Formation (Miocene), Northeast Japan. In Farinacci. A. (Ed.), Proc. II Planktonic Conf., Roma 1970: Rome (Edizioni Tecnoscienza), 2:689-703. 1972. Upper Cretaceous and Cenozoic silicoflagellates and ebridians. Bull. Am. Paleontol., 62:135-229.

, 1977. Late Cenozoic silicoflagellates and ebridians from the Eastern North Pacific region. First Int. Congr. Pacific Neogene Stratigraphy, Tokyo, 1976, Proc.: Tokyo (Kaiyo Shuppan Co.), pp. 205-233.

Ling, H. Y., and McPherson, L. M., 1974. Study on the ebridian genus Parathranium Hovasse. Rev. Espan. Micropaleontol., 6: 191-200.

Loeblich, A. R., III, Loeblich, L. A., Tappan, H., and Loeblich, A. R., Jr., 1968. Annotated Index of Fossil and Recent Silicoflagellates and Ebridians with Descriptions and Illustrations of Validly Proposed Taxa. Geol. Soc. Am. Mem., 106.

Martin, G. C., 1904. Systematic Paleontology, Miocene: Baltimore (Maryland Geological Survey and The Johns Hopkins Press).

Martini, E., 1979. Calcareous nannoplankton and silicoflagellate biostratigraphy at Reykjanes Ridge, northeastern North Atlantic (DSDP Leg 49, Sites 407 and 409). In Luyendyk, B. P., Cann, J. R., et al., Init. Repts. DSDP, 49: Washington (U.S. Govt. Printing Office), 533-550.

Martini, E., and Müller, C., 1976. Eocene to Pleistocene silicoflagellates from the Norwegian-Greenland Sea (DSDP Leg 38). In Talwani, M., Udintsev, G., et al., Init. Repts. DSDP, 38: Washington (U.S. Govt. Printing Office), 857-896.
Perch-Nielsen, K., 1975. Late Cretaceous to Pleistocene archeomonads, ebridians, endoskeletal dinoflagellates, and other siliceous microfossils from the subantarctic southwest Pacific, DSDP, Leg 29. In Kennett, J. P., Houtz, R. E., et al., Init. Repts. DSDP, 29: Washington (U.S. Govt. Printing Office), 873-907.

1976. New silicoflagellates and a silicoflagellate zonation in north European Palaeocene and Eocene diatomites. Bull. Geol. Soc. Denmark, 25:27-40.

, 1977. Tertiary silicoflagellates and other siliceous microfossils from the western South Atlantic, Deep Sea Drilling Project, Leg 39. In Supko, P. R., Perch-Nielsen, K., et al., Init. Repts. DSDP, 39: Washington (U.S. Govt. Printing Office), 863-868. 1978. Eocene to Pliocene archeomonads, ebridians, and endoskeletal dinoflagellates from the Norwegian Sea, DSDP Leg 38. In Talwani, M., Udintsev, G., et al., Init. Repts. DSDP, Suppl. to Vols. 38, 39, 40, and 41: Washington (U.S. Govt. Printing Office), 147-176.

Poelchau, H. S., 1974. Holocene silicoflagellates of the North Pacific: their distribution and use for paleotemperature determination [Ph.D. dissert.]. University of California, San Diego. 1976. Distribution of Holocene silicoflagellates in North Pacific sediments. Micropaleontology, 22:164-193.

Schulz, P., 1928. Beiträge zur Kenntnis fossiler und rezenter Silicoflagellaten. Bot. Arch., 21:225-292.

Tynan, E. J., 1957. Silicoflagellates of the Calvert Formation (Miocene) of Maryland. Micropaleontology, 3:127-136.

Van Valkenburg, S. D., 1970. The ultrastructure of the silicoflagellate Dictyocha fibula Ehrenberg [Ph.D. dissert.]. University of Washington.

1980. Silicoflagellates. In Cox, E. R. (Ed.), Phytoflagellates: New York (Elsevier-North Holland), pp. 335-350.

Van Valkenburg, S. D., and Norris, R. E., 1970. The growth and morphology of the silicoflagellate Dictyocha fibula Ehrenberg in culture. J. Phycol., 6:48-54.

Date of Initial Receipt: 27 March 1985

Date of Acceptance: 31 December 1985 


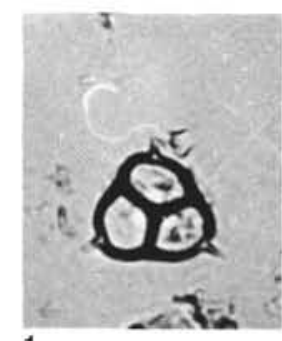

1
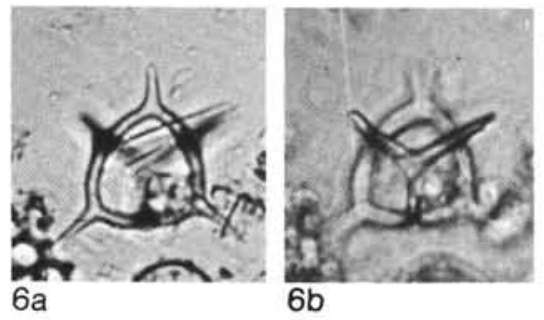

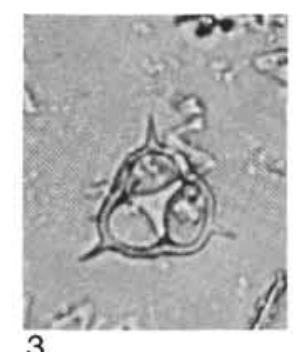

3

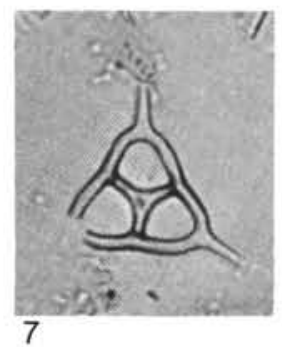

7

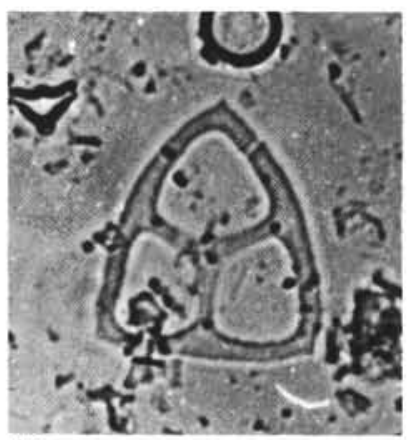

11

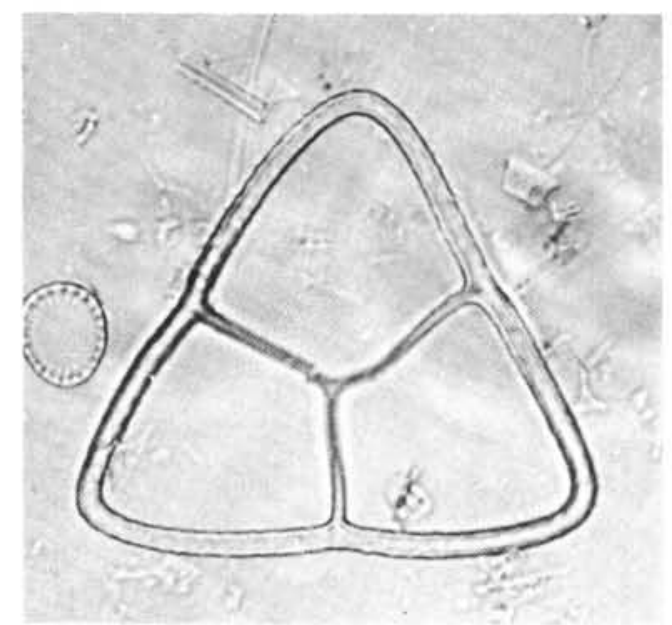

14

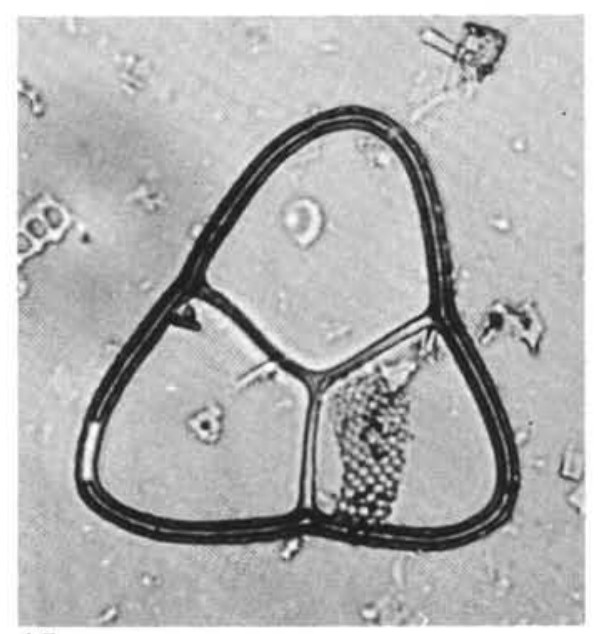

15

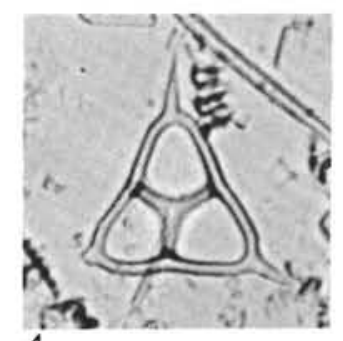

4

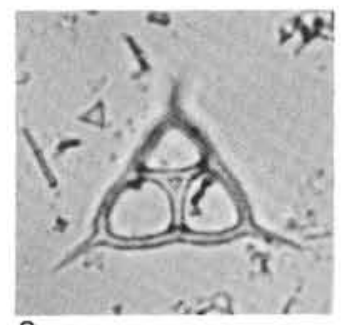

8

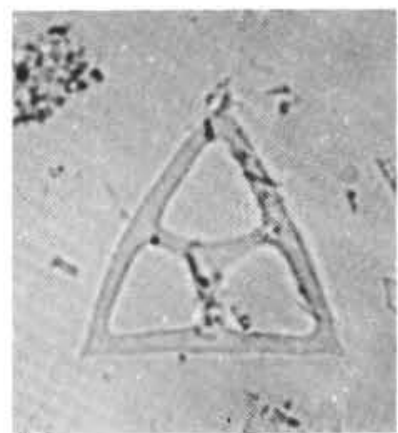

12
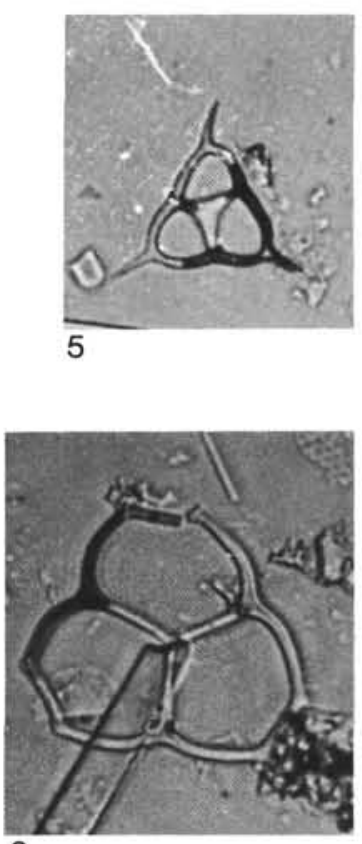

9

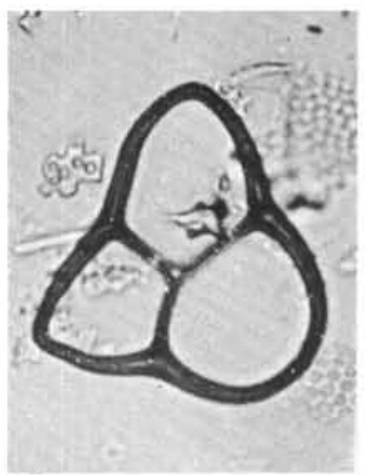

13

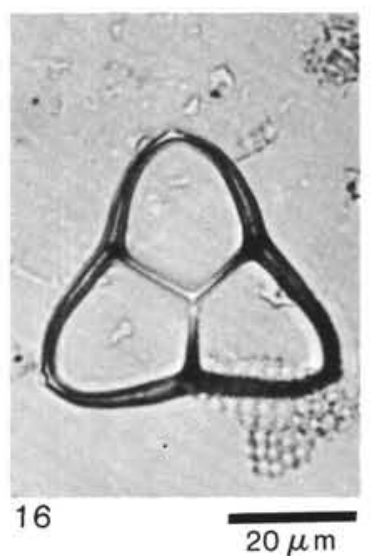

Plate 1. Silicoflagellates from Leg 93. (Magnification $640 \times$; scale bar $20 \mu \mathrm{m}$.) 1-5. Corbisema triacantha (Ehrenberg), (1-3) Sample 605-10-3, $20-22 \mathrm{~cm}$ (3, cruxoid), (4) Sample 605-16-6, 20-22 cm, (5) 605-13-6, 20-22 cm. 6. Dictyocha spinosa (Deflandre), Sample 605-16-6, 20-22 cm, (a) focusing on basal ring and (b) focusing on apical spines. 7, 8. Corbisema triacantha (Ehrenberg), cruxoid, Sample 605-10-3, 20-22 cm. 9. Corbisema bimucronata Deflandre, Sample 605-15-6, 20-22 cm. 11, 12. Corbisema recta (Schulz), (11) Sample 605-14-3, 20-22 cm, (12) Sample 605-13-6, 20-22 cm. 13. Corbisema cf. inermis inermis (Lemmermann), Sample 605-13-6, 20-22 cm. 14-16. Corbisema inermis inermis (Lemmermann), (14) Sample 605-11-3, 20-22 cm, (15) Sample 605-11-6, 20-22 cm, (16) Sample 605-17-6, 20-22 cm. 


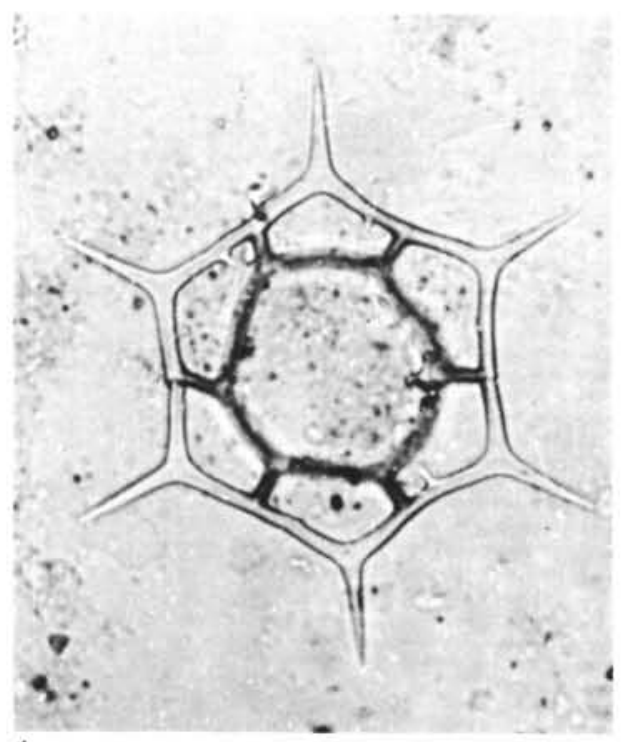

1

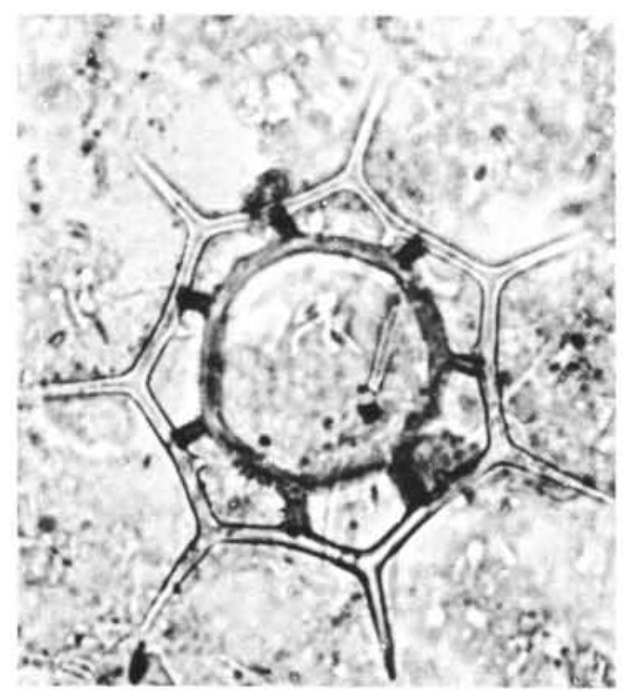

4

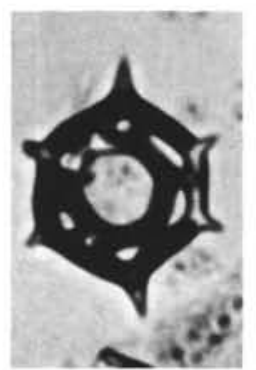

7

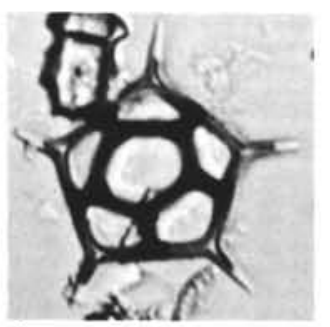

8

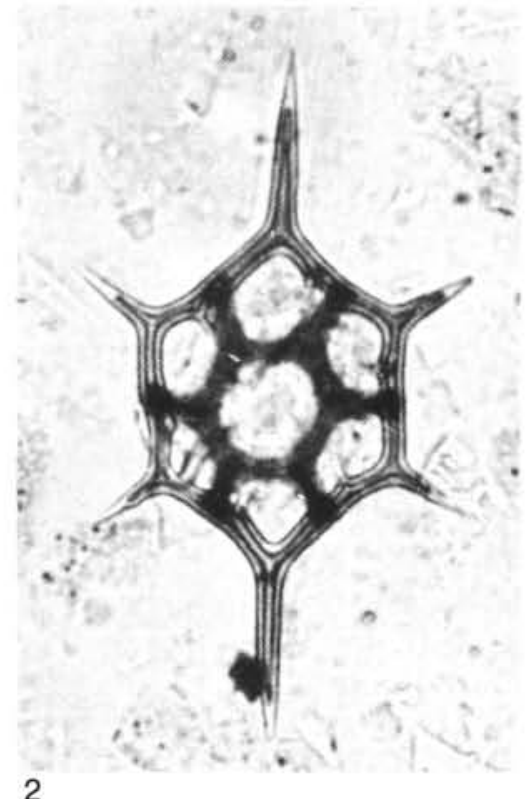

2

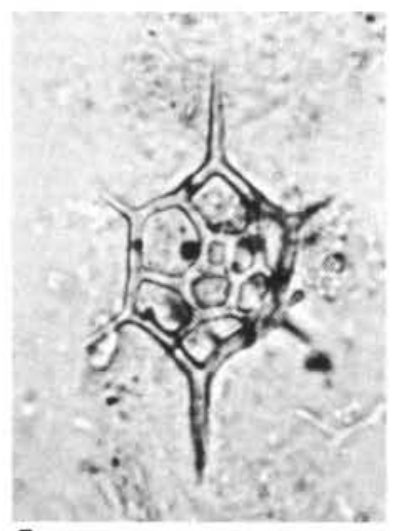

5

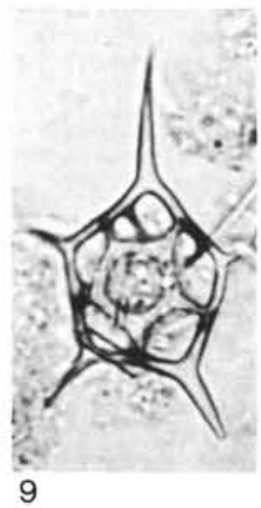

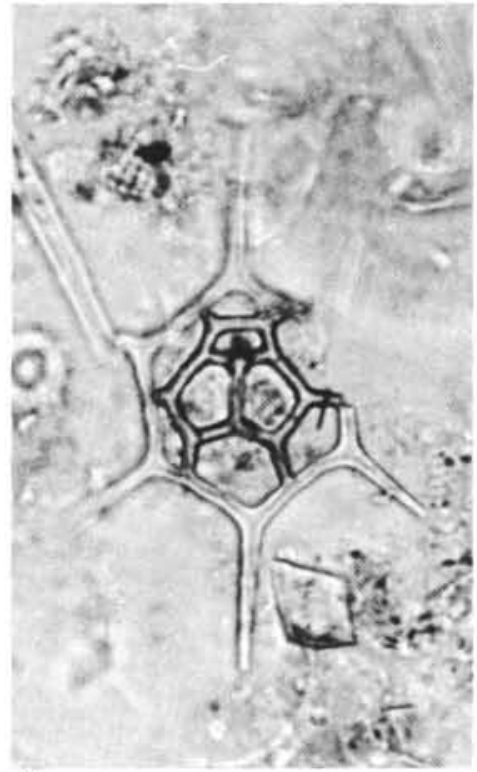

3
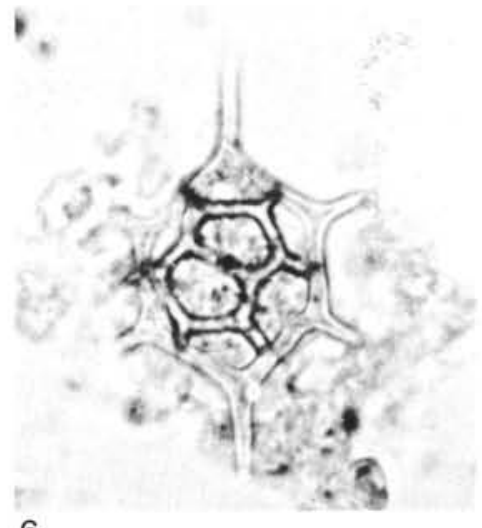

6

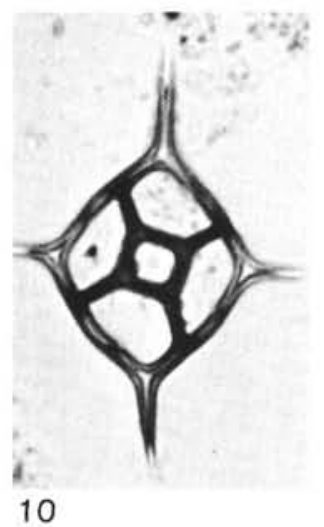

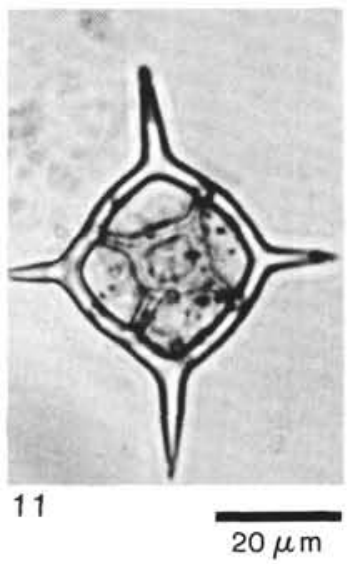

Plate 2. Silicoflagellates from Leg 93. (Magnification $640 \times$; scale bar $20 \mu \mathrm{m}$.) 1. Distephanus boliviensis (Frenguelli), Sample 604-23-1, 20-22 cm. 2. Distephanus speculum speculum (Ehrenberg), Sample 604-25-3, 20-22 cm. 3. Distephanus speculum hemisphaericus (Ehrenberg), Sample 604-23-2, 20-22 cm. 4. Distephanus boliviensis (Frenguelli), Sample 604-23-1, 20-22 cm. 5. Distephanus speculum hemisphaericus (Ehrenberg), Sample 604-23-2, 20-22 cm. 6. Distephanus speculum binoculus (Ehrenberg), Sample 604-23-1, 20-22 cm. 7. Distephanus speculum minutus (Bachmann), Sample 604-23-4, 20-22 cm. 8. Distephanus speculum pentagonus Lemmermann, Sample 605-13-6, 20-22 cm. 9. Distephanus speculum/crux, Sample 604-26-3, 20-22 cm. 10, 11. Distephanus crux (Ehrenberg), (10) Sample 604-26-3, 20-22 cm, (11) Sample 604-26-4, 20-22 cm. 


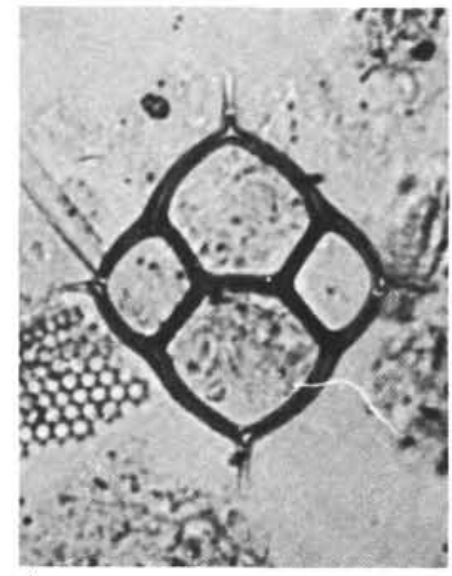

1

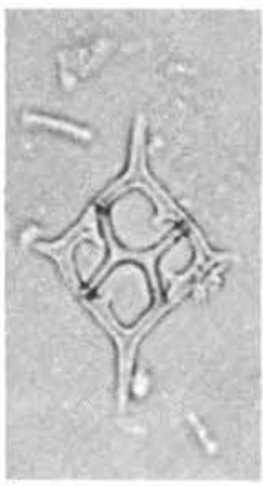

5

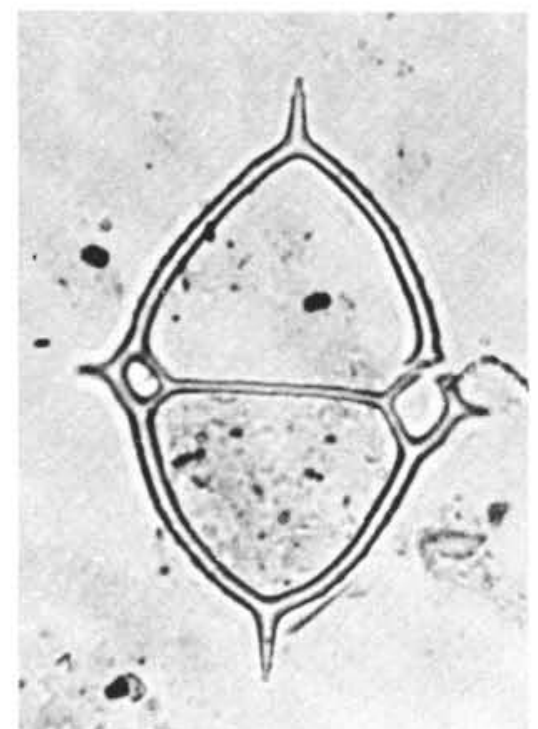

9

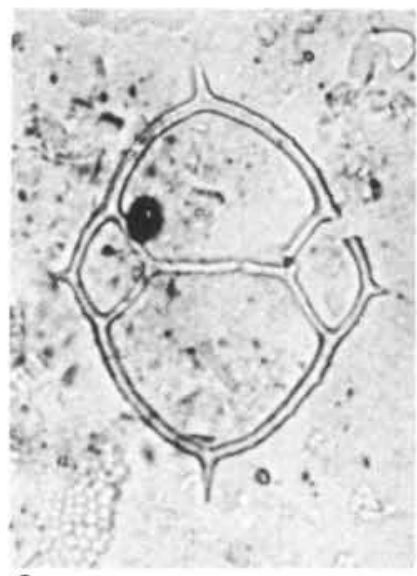

2

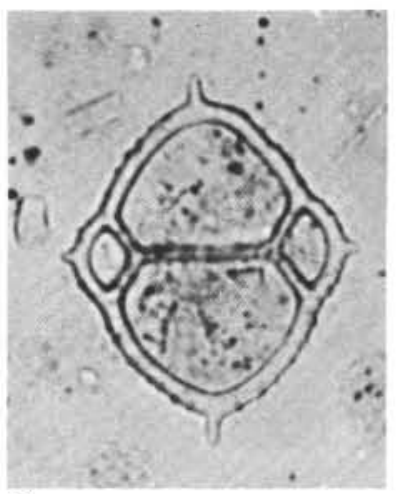

3

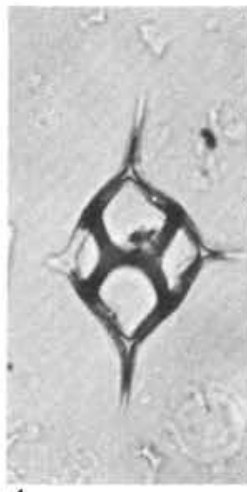

4

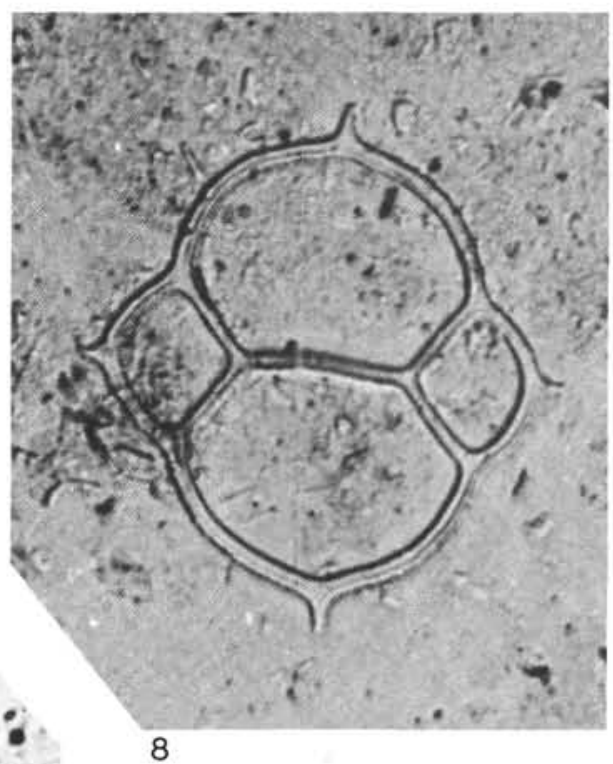

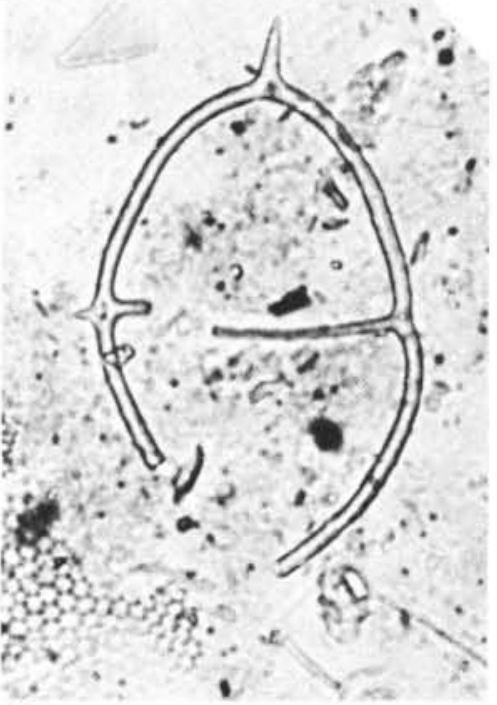

10

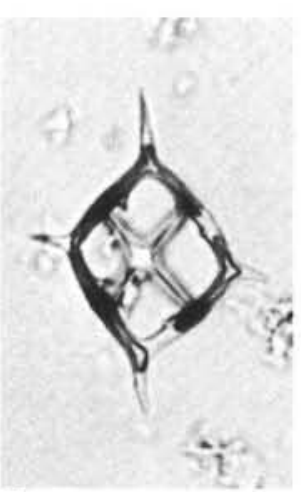

7

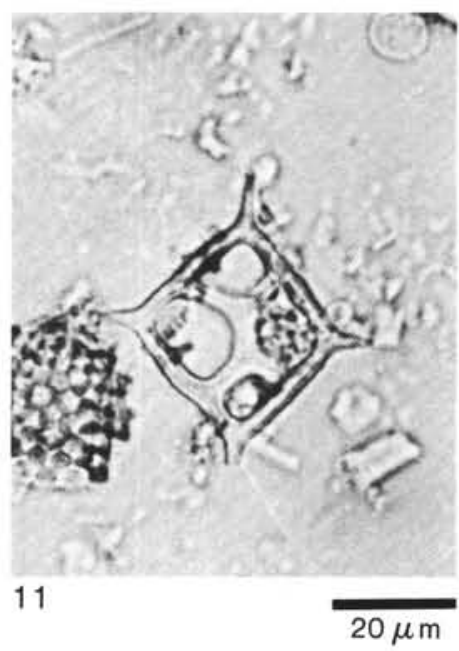

Plate 3. Silicoflagellates from Leg 93. (Magnification $640 \times$; scale bar $20 \mu \mathrm{m}$.) 1. Dictyocha aspera aspera (Lemmermann), Sample 604-26-4, 20-22 cm. 2, 3. Dictyocha brevispina (Lemmermann), Sample 604-23-2, 20-22 cm. 4-7. Dictyocha byronalis Bukry, (4) Sample 605-13-6, 20-22 cm, (5) Sample 605-15-6, 20-22 cm, (6) Sample 605-10-3, 20-22 cm, (7) medusoid, Sample 605-13-6, 20-22 cm. 8, 9. Dictyocha brevispi$n a$ (Lemmermann), (8) Sample 604-23-3, 20-22 cm, (9) Sample 604-23-1, 20-22 cm. 10. Dictyocha brevispina/transversa, Sample 604-23-1, $20-22 \mathrm{~cm}$. 11. Dictyocha byronalis Bukry, fibuloid, Sample $605-18-3,20-22 \mathrm{~cm}$. 


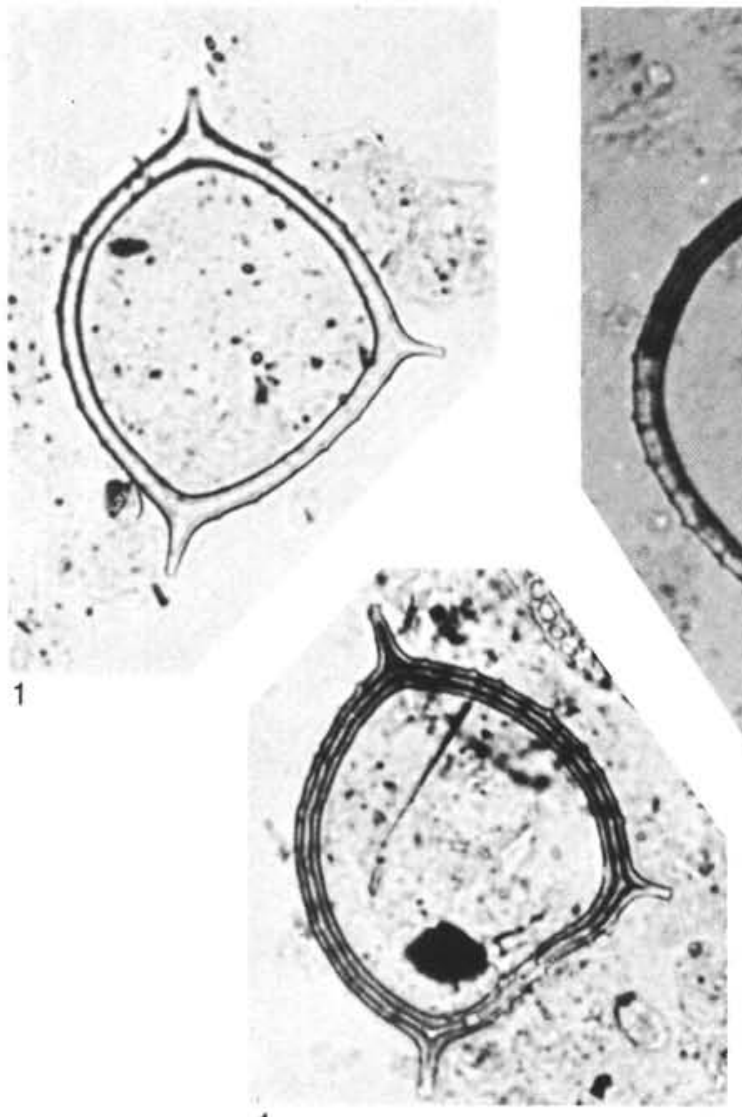

4

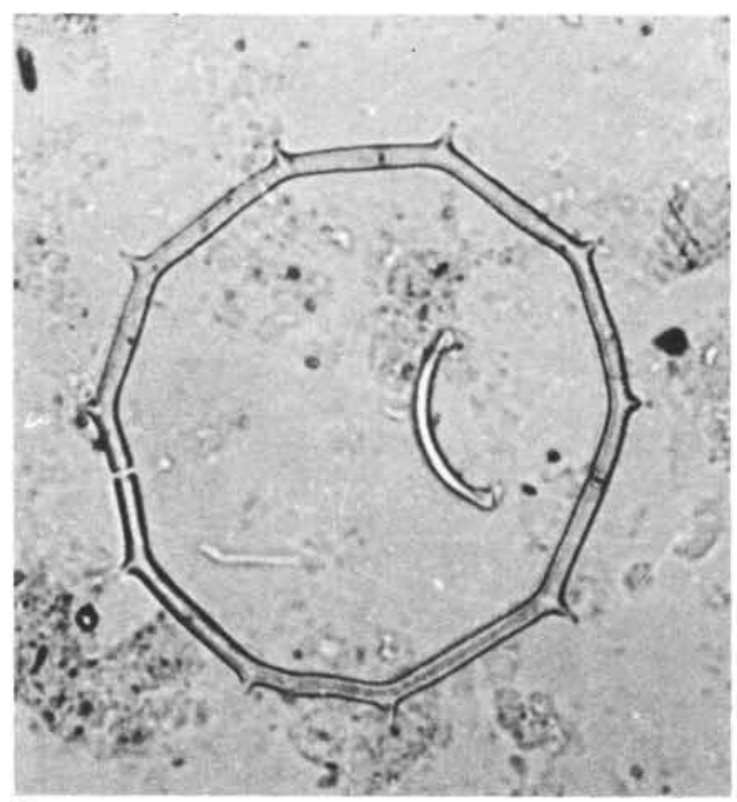

7
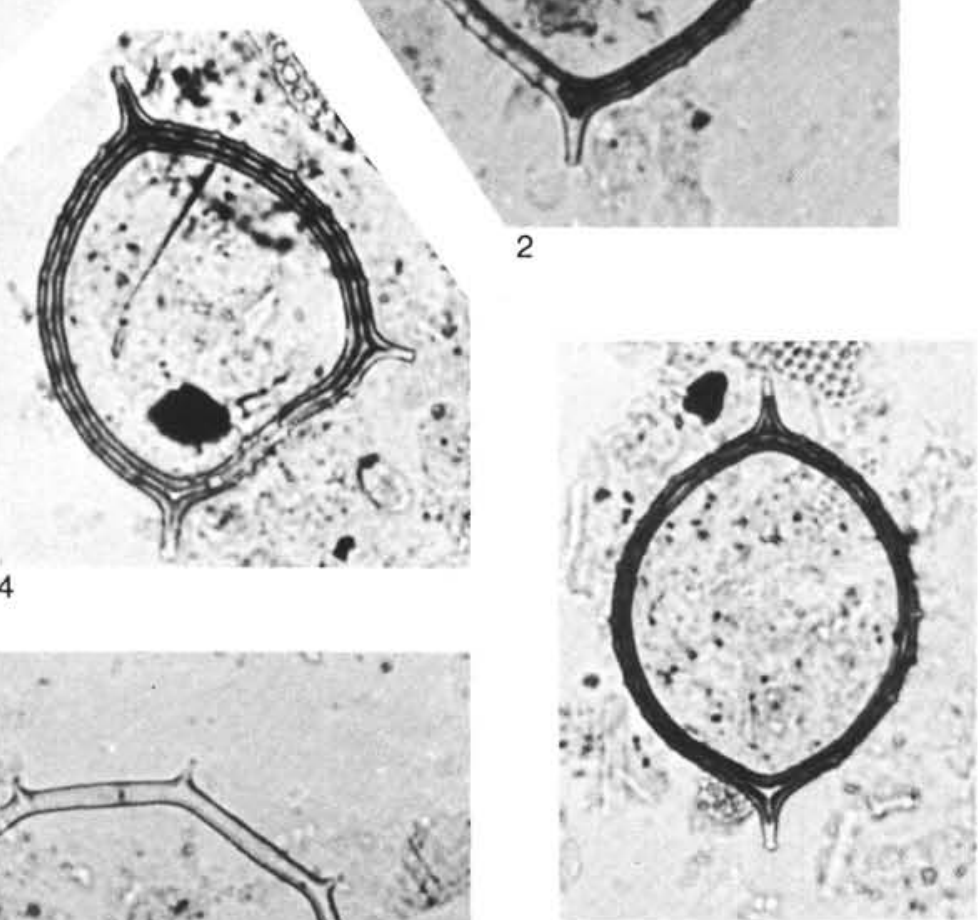

5

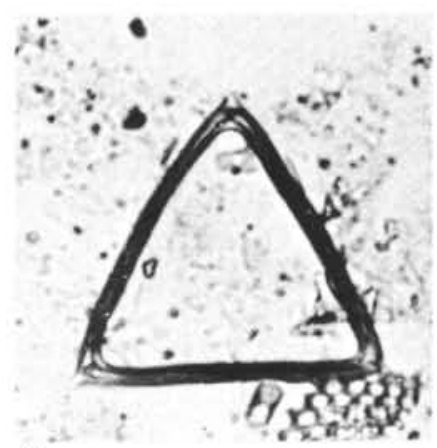

8

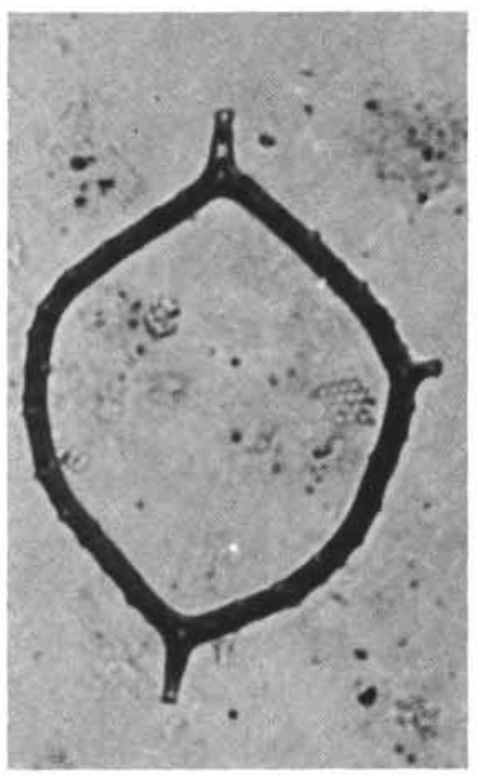

3

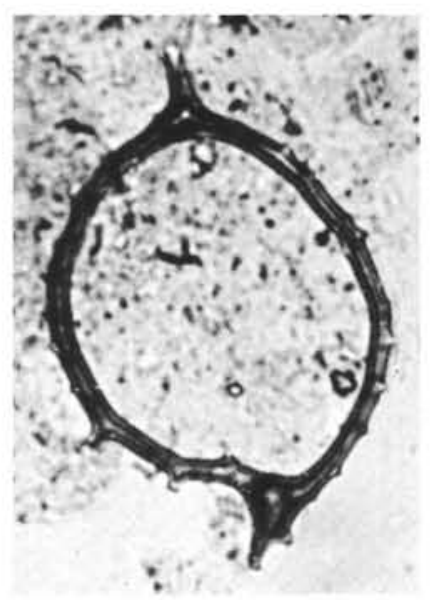

6

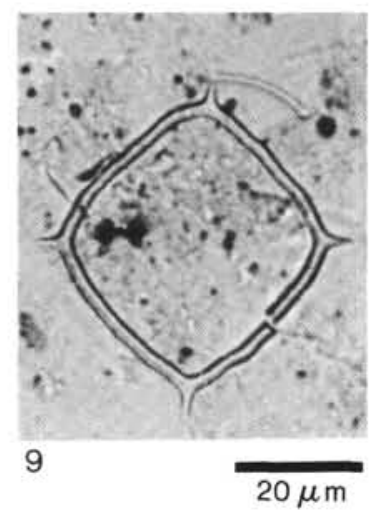

Plate 4. Silicoflagellates from Leg 93. (Magnification $640 \times$; scale bar $20 \mu \mathrm{m}$.) 1-4. Mesocena triodon Bukry, (1) Sample 604-26-4, 20-22 cm,

(2-4) Sample 604-25-2, 20-22 cm. 5, 6. Mesocena diodon Ehrenberg, (5) Sample 604-26-3, 20-22 cm, (6) aberrant, Sample 604-23-3, 20-22 $\mathrm{cm}$. 7. Mesocena circulus (Ehrenberg), Sample 604-25-2, 20-22 cm. 8. Mesocena apiculata Schulz, Sample 604-26-3, 20-22 cm. 9. Mesocena elliptica (Ehrenberg), Sample 604-23-1, 20-22 cm. 


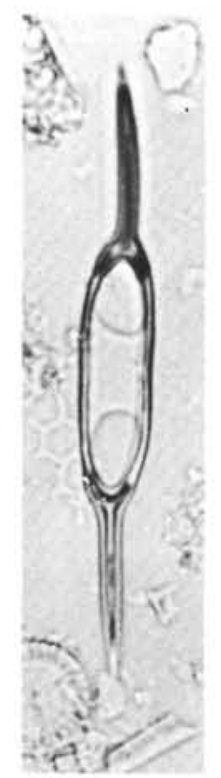

1

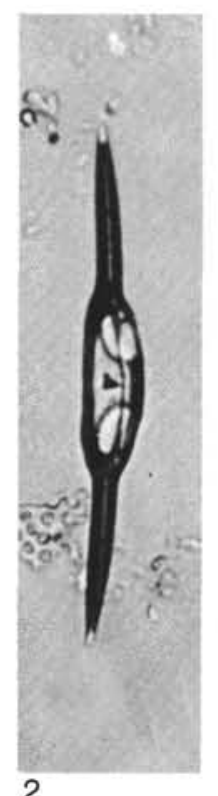

2

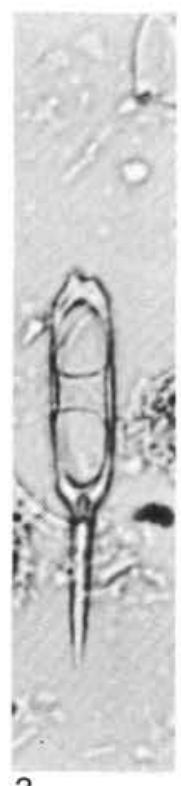

3
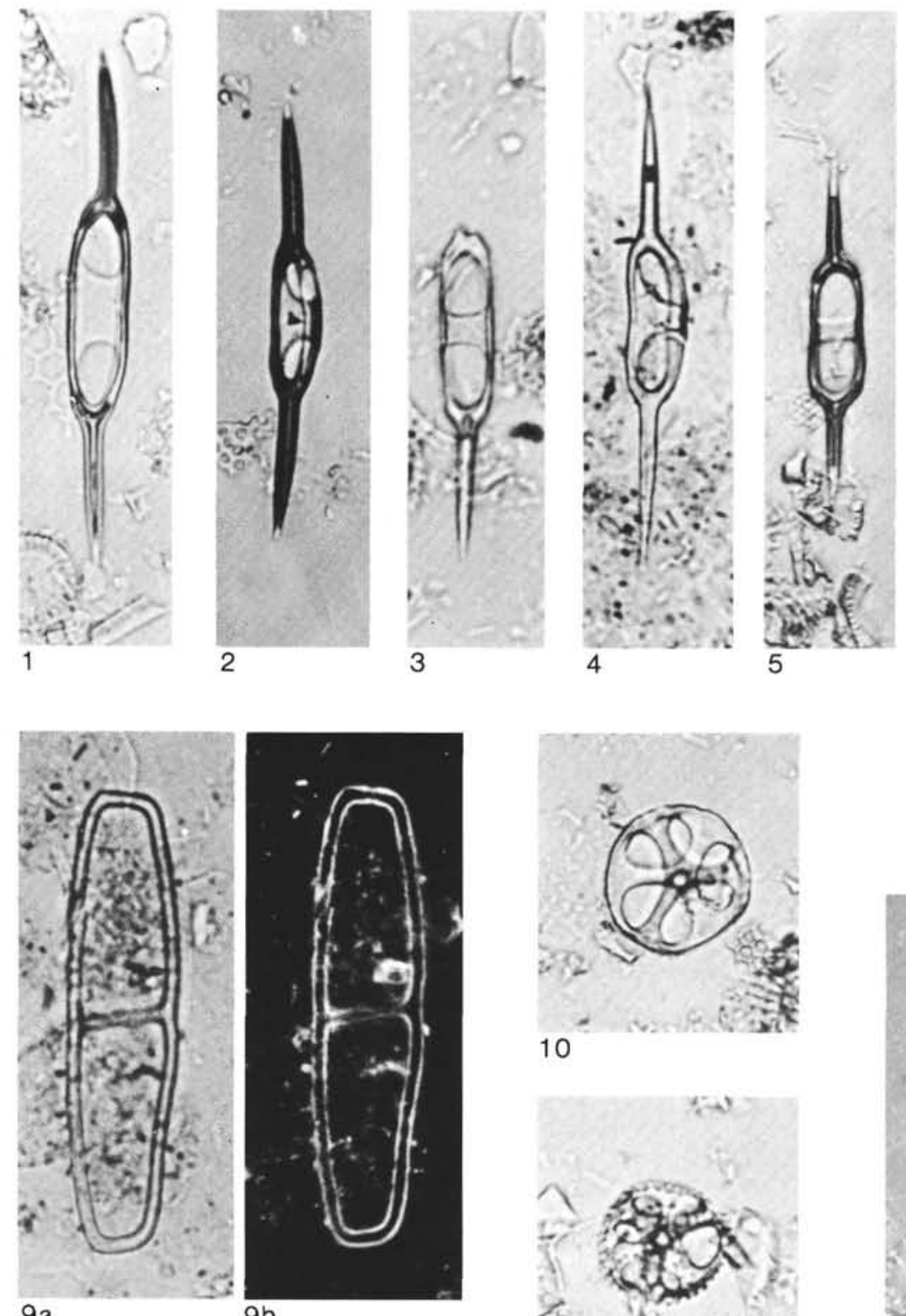

$9 b$
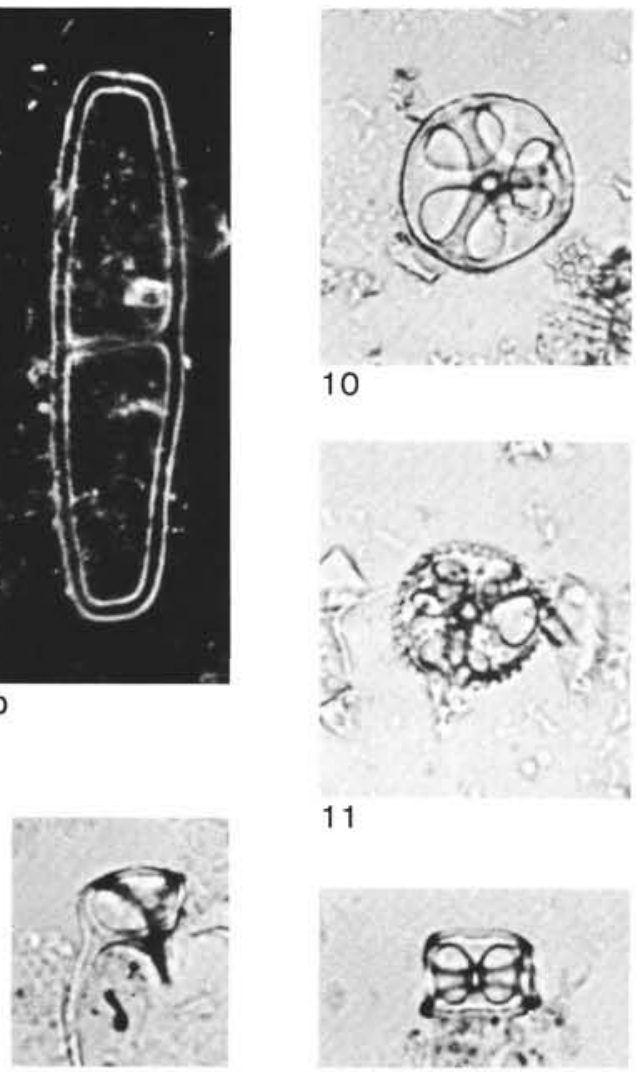

14

11

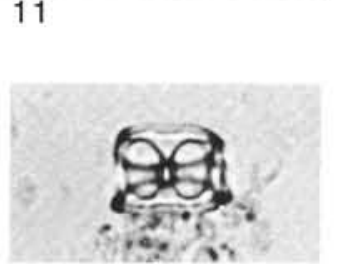

15
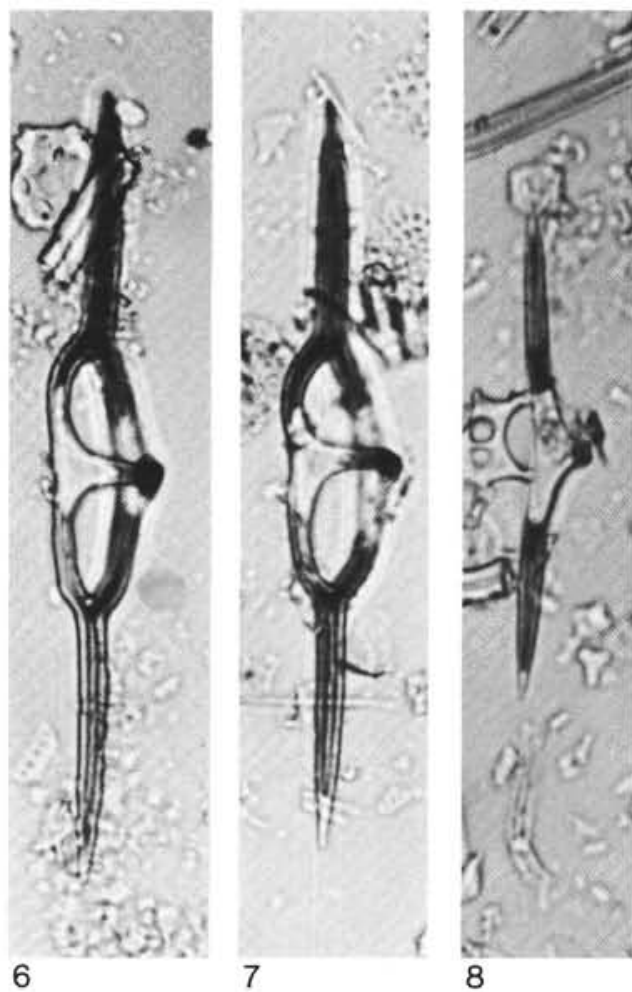

8

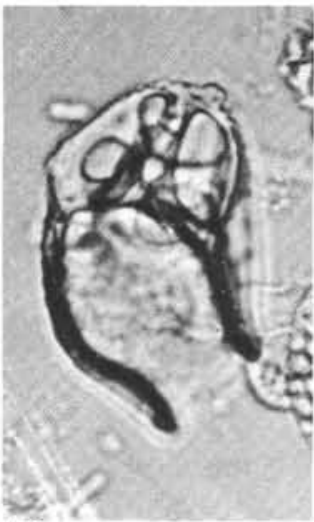

12

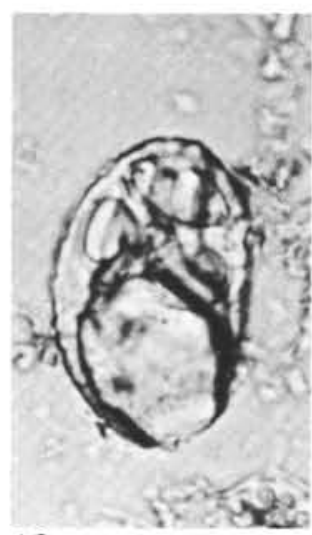

13

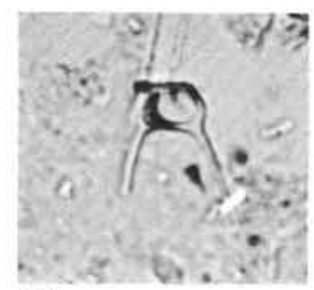

16

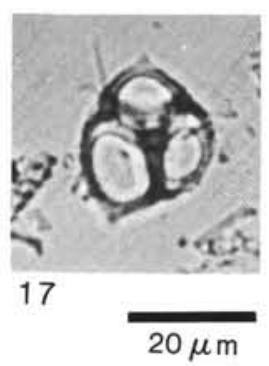

Plate 5. Silicoflagellates (Figs. 1-9) and ebridians (Figs. 10-17) from Leg 93. (Magnification $640 \times$; scale bar $20 \mu \mathrm{m}$.) 1, 2. Naviculopsis foliacea Deflandre, (1) Sample 605-10-3, 20-22 cm, (2) Sample 605-18-3, 20-22 cm. 3, 4. Naviculopsis constricta (Schulz), (3) Sample 605-16-6, 20-22 cm, (4) Sample 605-26-3, 20-22 cm. 5-8. Naviculopsis eobiapiculata Bukry, (5) Sample 605-13-6, 20-22 cm, (6) Sample 605-19-3, 20-22 cm, (7) Sample 605-19-6, 20-22 cm, (8) Sample 605-13-3, 20-22 cm. 9. Naviculopsis ponticula, Sample 604-23-3, 20-22 cm (a) standard transmitted light, (b) dark field (reflected light) 10. Ebriopsis antiqua antiqua (Schulz), Sample 605-19-6, 20-22 cm. 11. Ebriopsis crenulata Hovasse, Sample 605-19-6, 20-22 cm. 12, 13. Ebriopsis antiqua antiqua with lorica, (12) Sample 605-10-3, 20-22 cm, (13) Sample 605-21-3, 20-22 cm. 14. Parathranium tenuipes Hovasse, Sample 604-26-1, 20-22 cm. 15. Ammodochium rectangulare (Schulz), Sample 604-26-4, 20-22 cm. 16. Parathranium tenuipes Hovasse, Sample 604-26-1, 20-22 cm. 17. Ebriopsis antiqua cornuta Ling, Sample 605-10-3, 20-22 cm. 